\title{
MEASURING VALUE-ADDED-ORIENTED BIM CLIMATE IN CONSTRUCTION PROJECTS: DIMENSIONS AND INDICATORS
}

\author{
Lei ZHANG ${ }^{1}$, Jingfeng YUAN(1*1*, Nini XIA ${ }^{1} 1$, Yan $\mathrm{NING}^{2}$, Junwei MA ${ }^{1}$, \\ Mirosław J. SKIBNIEWSKI ${ }^{(1)} 3,4,5$ \\ ${ }^{1}$ Department of Construction and Real Estate, Southeast University, Nanjing P. R. China \\ ${ }^{2}$ School of Management and Engineering, Nanjing University, Nanjing P. R. China \\ ${ }^{3}$ Department of Civil and Environmental Engineering, University of Maryland, College Park, USA \\ ${ }^{4}$ Institute for Theoretical and Applied Informatics, Polish Academy of Sciences, Gliwice, Poland \\ ${ }^{5}$ Chaoyang University of Technology, Taichung, Taiwan
}

Received 26 July 2020; accepted 23 October 2020

\begin{abstract}
A value-added-oriented (VAO) BIM climate is the organizational climate of BIM value-added. However, a lack of research on VAO BIM climate has thwarted progress on BIM knowledge systems. By using the socio-technical systems approach and the competing value approach, 12 dimensions and 39 indicators of a VAO BIM climate are proposed and tested using 306 questionnaires collected from workers engaged in BIM construction projects across China. Data was analyzed by confirmatory factor analysis. The results show that the proposed dimensions and indicators are highly reliable and valid. The VAO BIM climate is heavily influenced by autonomy, career development, and task orientation. The top 10 indicators were mainly related to participation, task orientation, and goal effectiveness. And the MWD-BIM, RCS-BIM, CDMT-BIM, and SMD-BIM were mistaken as key indicators of participation, autonomy, peer relations, and organizational adaptability, respectively. The proposed dimensions and indicators can be used to advance scholarly understanding and theory on BIM climate in construction projects through directing resource allocation, enhancing the understanding of human-BIM interactions, improving the BIM knowledge system and facilitating decision framework of BIM adoption. Practical implications for managers in construction projects are provided in the end.
\end{abstract}

Keywords: construction projects, value-added, BIM climate, dimensions, indicators.

\section{Introduction}

Building information modeling (BIM) refers to "a shared knowledge resource for information about any built objects" (Yin et al., 2019). BIM focuses on integrating the information of all participants of a project (Santos et al., 2017) to generate an approach to manage the essential data involved in the lifecycle of a project (Wong \& Zhou, 2015) as well as changes to processes in it (Cheng et al., 2016). Given its potential to increase efficiency and productivity in the construction industry, BIM has been widely used in construction projects, railway infrastructure, and underground transportation tunnels (Cheng et al., 2016; Lu et al., 2019; Häußler \& Borrmann, 2020; Heravi et al., 2019; Hu et al., 2019). However, the relatively low scale of the adoption of BIM, and the fact that it has not been applied in detail, have hindered its maximal use. Previous studies have identified factors that facilitate BIM implementation, such as client support, image motives, economic motives, the compatibility and integration of BIM, and BIM training (Cao et al., 2016; Ding et al., 2015). The relevant policies and standards for BIM have thus been established to enhance the frequency of its use (Jin et al., 2017a). Although these efforts have helped increase the implementation of BIM to some extent, multiple disadvantages, such as the unacceptability of BIM policy, an inadequate BIM-related management system, and poor understanding of the BIM process, have offset the increasing trend of BIM adoption (Davies et al., 2017; Xu et al., 2018). This phenomenon is more common and representative in construction projects, China (Chan et al., 2018; $\mathrm{Xu}$ et al., 2018). Thus, it is that rely on the investment in

*Corresponding author. E-mail: jingfeng-yuan@outlook.com

Copyright $\odot 2020$ The Author(s). Published by Vilnius Gediminas Technical University

This is an Open Access article distributed under the terms of the Creative Commons Attribution License (http://creativecommons.org/licenses/by/4.0/), which permits unrestricted use, distribution, and reproduction in any medium, provided the original author and source are credited. 
BIM policies and technologies cannot fully achieve BIM adoption alone, some complementary methods must be explored to accelerate BIM adoption.

The BIM climate can reflect the perception of BIM management in a construction project, and influences the behavior of its users, where this in turn affects the promotion and implementation of BIM (Liu et al., 2019; Xu et al., 2018). Nevertheless, focusing on the BIM climate alone is not enough, and the values of BIM should be considered simultaneously (Liu et al., 2019). Perceptions of valueadded can motivate the adoption of BIM, and should be assessed to remove barriers to its implementation (Zheng et al., 2019). Therefore, value-added-oriented (VAO) BIM climate, which compensates for the weaknesses of the BIM climate and reveals the characteristics of BIM value, may be indispensable to the implementation of BIM. The VAO BIM climate shares perceptual attributes with BIM value-added, and is characterized by a limited number of dimensions (Jones et al., 1979). Previous studies have established the dimensions and indicators of different work climates, such as the ethical climate (Arnaud, 2010), the safety climate (Dahl \& Olsen, 2013), the innovation climate (Liu \& Chan, 2017), and the justice climate (Li \& Cropanzano, 2009). However, little research has examined the VAO BIM climate. Although Xu et al. (2018) proposed dimensions (i.e. general perception, staff involvement, risk perception, etc.) of the BIM climate from the perspective of safety, these dimensions are limited in terms of measuring the VAO BIM climate. Moreover, despite the stated benefits of BIM, Xu et al. (2018) failed to articulate the important role of BIM in solving problems in construction project management.

To fill the above gap in research, this study explores the appropriate dimensions of the VAO BIM climate and establishes a list of indicators for measuring them. By establishing the dimensions and indicators, this study will contribute to developing managers' understanding of BIM, reasonably allocating resources to key areas of BIM management, and supporting development of decision framework for BIM adoption in construction projects. By using these dimensions and indicators in the context of construction projects, managers can assess BIM climate levels and find weak aspects that need to be strengthened, thereby advancing the implementation of BIM in construction projects.

\section{Background}

\subsection{BIM climate in construction projects}

Organizational climate refers to "a set of shared perceptions regarding the policies, practices, and procedures that an organization rewards, supports, and expects" (Kuenzi \& Schminke, 2009). Using the definition of safety climate (common perceptions regarding safety) as a reference (Shen et al., 2015), BIM climate refers to a set of shared perceptions of the policies, practices, and procedures relating to BIM that rewarded, supported, and expected by the organization of a construction project. Individu- als' perceptions of BIM and their shared attitudes toward BIM build the BIM climate in project management areas (Xu et al., 2018). Inspired by the role of organizational climate proposed by Coda et al. (2015), BIM climate represents individual subjective perceptions and experiences regarding BIM, and treats the relevant policies, practices, and procedures as perceived contents. The BIM climate is considered to be a factor influencing information management and performance in construction projects. It has a direct effect on BIM adoption behaviors and supports the implementation of BIM in construction projects (Caniëls et al., 2019; Liu \& Chan, 2017). This phenomenon will further influence information management and project performance through better information sharing and organizational collaboration (Mahalingam et al., 2015). The factors affecting the BIM climate can be summarized as either general or special factors. General factors influence the entire organizational climate, including the BIM climate. The hierarchical positions of people, communication, standards, sanctioning systems, management practices, and actions can impact the organizational climate through sense-making processes (Araten-Bergman, 2016; Beus et al., 2012; Kaya et al., 2010). Special factors are ones that pertain to the BIM climate. Xu et al. (2018) made an analogy between the BIM climate and the safety climate, and argued that regional differences, professions, experiences, and organizations can constitute individual BIM perceptions that form the BIM climate. In less BIMmature regions, the type and size of the organization are relevant factors in practice-based perceptions of BIM (Liu et al., 2019).

\subsection{Socio-technical systems approach}

The socio-technical systems (STS) approach is used to describe the outputs of a work system by considering human, social, organizational, and technical factors (Jin et al., 2019). It assumes that the outputs depend on two interrelated and interacting subsystems: the technical system and the social system (Swuste et al., 2020; Winby \& Mohrman, 2018). The technical system, the outcomes of which are efficiency and competitive advantage, aims to transform resources into outputs (Bostrom \& Heinen, 1977b; Melville et al., 2004). The social system the outcomes of which are the quality of work life, reflects ways in which individual tasks are accomplished and the extent of satisfaction drawn by individuals from them (Bostrom \& Heinen, 1977b). Rather than optimizing a particular dimension, the STS approach focuses on optimizing the entire work system (Pasmore \& Khalsa, 1993). It emphasizes the induced effects of technologies and bottom-up process-oriented views (Closs et al., 2008; Fairhurst et al., 1995; Swuste et al., 2020). As a socio-technical system, BIM comprises a technical system and a social system (Liu et al., 2017). BIM value-added, which consists of improving efficiency improvement, competitive advantage, and quality of work life, is produced by the interaction between these systems. On the one hand, BIM is a technical tool for improving project efficiency and competitive 
advantages (Liu et al., 2017; Stewart \& Mohamed, 2003). On the other hand, BIM acts as a social method to change the ways of working (Holmström et al., 2015; Liu et al., 2017; Stewart \& Mohamed, 2003).

\subsection{BIM value and value-added}

BIM value is defined as the impacts of BIM technology on the performance of a construction project in terms of impacts on efficiency, competitiveness, and quality of work life (Bostrom \& Heinen, 1977a; Melville et al., 2004; Zheng et al., 2019). The impacts on efficiency mean that BIM can help realize the goals of the construction project related to cost, time, and scope (Serrador \& Turner, 2015; Zheng et al., 2019). Competitive impacts indicate that BIM enables organizations to achieve and use resources of information more effectively in construction projects (March, 1991; Papadonikolaki, 2018; Sackey et al., 2015). Impacts of the quality of work life refer to the fact that BIM can lend more interesting, challenging, and responsible perceptions to workers in construction projects (Almuntaser et al., 2018; Bostrom \& Heinen, 1977a). BIM value is the basis for judging the success of BIM implementation, and can guide best practices (Kim et al., 2017; Zheng et al., 2019). Previous studies have shown that organizational culture, communication, workers' skills, and the relevant policies and principles can facilitate the realization and optimization of the value of investment in BIM (Alreemy et al., 2016). Absorptive capacities can enhance organizations' understanding of operational logic, which promotes the identification of the practical value of BIM (Park et al., 2007). Jin et al. (2017b) have identified the interoperability of BIM software as the most important factor for achieving BIM value.

According to the BIM value, BIM value-added refers to the improvement in the performance of the construction project resulting from the use of high-levels of BIM technology in the relevant processes. An improvement in performance is measured in terms of improvements in efficiency, competitive advantage, and quality of work life
(Bostrom \& Heinen, 1977a; Melville et al., 2004; Saunders, 1999; Zheng et al., 2019). In line with STS, improvements in efficiency and competitive advantage are produced by the technical system, and that in the quality of work life is brought about by the social system (Bostrom \& Heinen, 1977b; Neely et al., 2014; Uhrin et al., 2017). On the one hand, technical systems including BIM processes, BIM technology, and well-accomplished tasks can ensure the more accurate pursuit of the objectives of the construction project (Crane et al., 1999; Olawumi \& Chan, 2018), develop real-time communication among participants (Lee et al., 2020; Liu et al., 2017; Wang et al., 2014), and help achieve the organizational goals of construction projects (Klein, 2007; Lee et al., 2020), respectively. On the other hand, a social system involving individual needs, the internal work system, external environment of the work system, and support systems helps satisfy workers' needs (Allen et al., 2003; Downey et al., 1975; Fee et al., 2017; Parasuraman et al., 1992; Park et al., 2008), enhances relations between workers (Methot et al., 2018), provides a stable environment (Sung et al., 2017), and relieves the litigation mentality of workers (Bies \& Tyler, 1993), respectively. Thus, the characteristics of BIM value-added in construction projects can be represented from seven aspects: ensuring the more accurate pursuit of construction project objectives, developing real-time communication among participants, presenting organizational achievement, satisfying workers' needs, enhancing the relations between workers, providing a stable environment, and relieving the litigation mentality of workers.

\section{Selecting dimensions of value-added-oriented BIM climate}

\subsection{Overview of selecting VAO BIM climate dimensions}

An overview of selecting VAO BIM Climate dimensions is presented in Figure 1. These dimensions were gleaned from a review of the literature. The selecting process de-

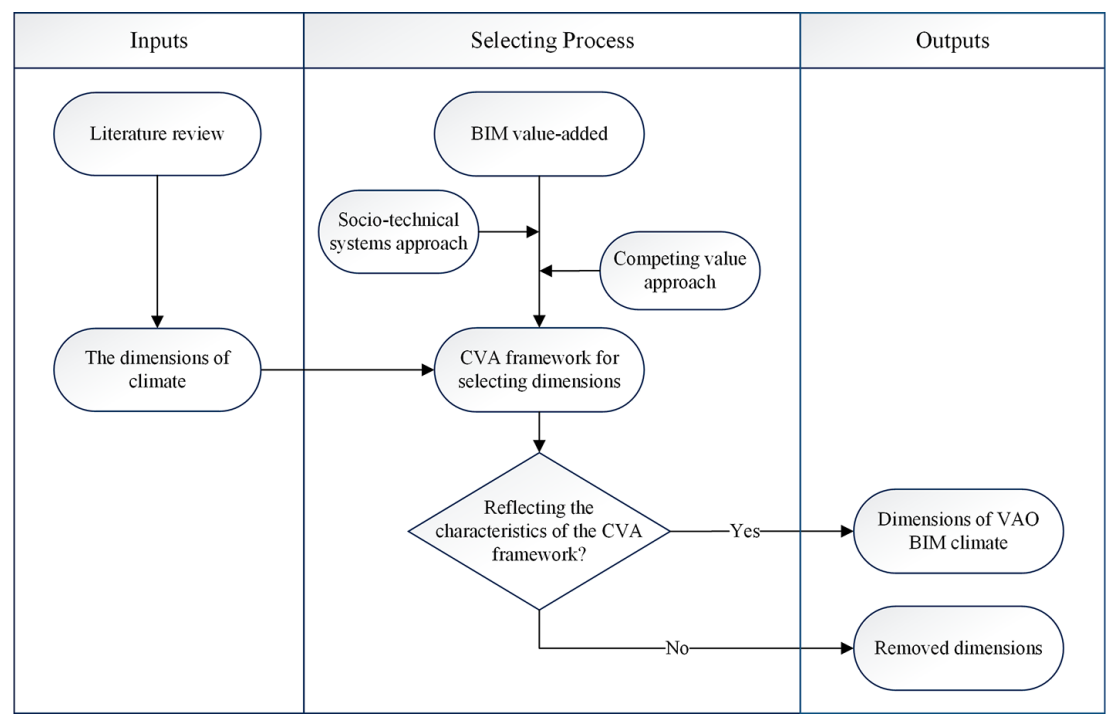

Figure 1. Overview of selecting VAO BIM climate dimensions 
pends on the competing value approach (CVA), which reflects the characteristics of BIM value-added. The process is detailed in the sections below. According to the characteristics of the CVA framework, two outputs involving dimensions of VAO BIM Climate and removed dimensions are produced by the selecting process.

\subsection{The dimensions of climate}

Organizational climate, including the dimensions of global climate and facet-specific climate, can be described by a limited number of dimensions (Kuenzi \& Schminke, 2009; Patterson et al., 2005). These dimensions can be divided into two categories: general and specific dimensions. General dimensions reflect the common characteristics of organizational climate (Kuenzi \& Schminke, 2009). For example, Schulte et al. (2009) identified rewards, communication, employee relationships, and job adequacy as dimensions of organizational climate. Denison (1996) proposed 11 climate dimensions: structure, support, risk, identity, standards, centralization, innovation, peer relations, motivation to achieve, cohesion, and pressure. Van De Voorde et al. (2010) suggested five general dimensions: goal emphasis, means emphasis, reward orientation, task support, and socio-emotional support. Specific dimensions are related to particular organizational climates, such as those of safety, justice, innovation (Kuenzi \& Schminke, 2009). For instance, Alruqi et al. (2018) reviewed the literature on the safety climate and suggested five safety dimensions associated with performance: management commitment to safety, supervisor safety role, safety rules and procedures, training, and individual responsibility for health and safety. Li et al. (2013a) explored three dimensions of the justice climate: distributive peer justice climate, procedural peer justice climate, interpersonal peer justice climate. Remneland-Wikhamn and Wikhamn (2011) used innovation and flexibility, outward focus, and reflexivity to measure open innovation climate.

\subsection{Competing value approach framework for selecting dimensions}

The CVA framework for selecting dimensions is the core section supporting the selecting process (see Figure 1). Two requirements, following the CVA theoretical model and revealing the characteristics of BIM value-added, should be satisfied simultaneously in the framework. Two steps are correspondingly designed to establish the CVA framework. In step 1, the theoretical model of CVA is introduced, and in step 2, the characteristics of BIM valueadded are connected with it to build the CVA framework for selecting dimensions. A detailed description of the two steps is provided below.

The two best-known paradigms for identifying facetspecific climate dimensions are the organizational climate questionnaire (OCQ) and the competing value approach (CVA) (Patterson et al., 2005), where the latter is superior to the former in many respects. CVA presents wider managerial ideologies, encapsulates major approaches to organizational values into a framework, is applied more widely in different organizations, aids inclusiveness, taps into core organizational values, and ensures that the selected dimensions are not duplicated (Patterson et al., 2005). CVA assumes that the dimensions of organizational climate are based primarily on individual perception (Van Vianen \& Kmieciak, 1998). Three sets of competing values are suggested by CVA to help understand the dimensions of organizational climate (Quinn \& Rohrbaugh, 1981). The first set is flexibility versus control, which focuses on organizational structure; the second set is internal versus external, which emphasizes individual well-being and development; the third set is means versus ends, which underlines important processes and final outcomes (Quinn \& Rohrbaugh, 1983). The theoretical model of CVA has four quadrants: (i) the human relations model, (ii) the internal process model, (iii) the open system model, and (iv) the rational goal model (Sinha \& McKim, 2000). These four models together provide a framework for sorting the dimensions of the organizational climate (Quinn \& Rohrbaugh, 1983).

The first two sets of the CVA form a framework for selecting dimensions. Traditional CVA emphasizes the human relations model for the quadrant (internal flexibility), and its core characteristics are the workers' wellbeing, growth, and commitment (Patterson et al., 2005). BIM value-added for this quadrant should support satisfying the workers' needs in construction projects. Three means - reward policy, training, and empowerment - contribute to satisfying them, and result in human resource development (Khan \& Ahmad, 2011). The internal focus in this quadrant is individual satisfaction, and the flexibility focus is the individual's different requirements. The internal control quadrant has been identified as the internal process model. Traditionally, the main goal of this quadrant is maintaining a sense of continuity and security in the individual (Quinn \& Rohrbaugh, 1983). In the context of BIM value-added, the quadrant is used to enhance relations between workers in construction projects. Communication and cohesion can facilitate relationships among workers to maintain organizational stability in construction projects (Barrick et al., 2007; Quinn \& Rohrbaugh, 1983). The internal focus in this quadrant is the individual's satisfaction with the inherent connections of workers, and the control focus is the sufficient coordination between them. The open system model (external flexibility) normally reflects organizational capabilities to adapt to the environment and seek resources therein (Patterson et al., 2005). Corresponding to BIM value-added, this quadrant emphasizes the development of real-time communication among participants and the provision of a stable environment. Through readiness and innovation, the characteristics can be supported by information management and organizational adaptability (Rafferty et al., 2013; Selçuk Çıdık et al., 2017; Sun \& Jeyaraj, 2013). The external focus in this quadrant is the development of organizations that undertake construction projects, and the flexibility focus is the organizational openness to innovate 
and implement BIM technology. The rational goal model (external control) is the quadrant that stresses productivity and goal achievement (Fan \& Shen, 2011). When attention is paid to BIM value-added, this quadrant is related to ensuring the more accurate pursuit of the objectives of the construction project, presenting organizational achievement, and relieving the litigation mentality of workers. Organizations can maintain these characteristics through designing (i.e., fair rules and procedures) and goal setting (Bies \& Tyler, 1993; Ren et al., 2019; Won \& Lee, 2016). The external focus in this quadrant reflects the development of construction project organizations, and the control focus reflects the achievement of construction project objectives. The CVA framework for selecting dimensions is shown in Figure 2.

\subsection{Dimensions of value-added-oriented BIM climate}

Similar to the definition of BIM climate, VAO BIM climate refers to a set of shared perceptions regarding the policies, practices, and procedures relating to BIM valueadded that are rewarded, supported, and expected by an organization undertaking a construction project. The dimensions of VAO BIM climate are used to represent it. Corresponding to the four quadrants in Figure 2, the dimensions that can reflect their characteristics are selected from the constructed pool of climate dimensions and contextualized in line with BIM value-added in construction projects. The process whereby the dimensions are selected and contextualized is presented below.

In the human relations model, reward orientation, career development, participation, autonomy, and train focus are selected to reflect satisfaction of workers' needs in construction projects. Workers' needs in construction projects include fair pay (Dabke et al., 2008), opportunity for promotion (advancement opportunities and capacities

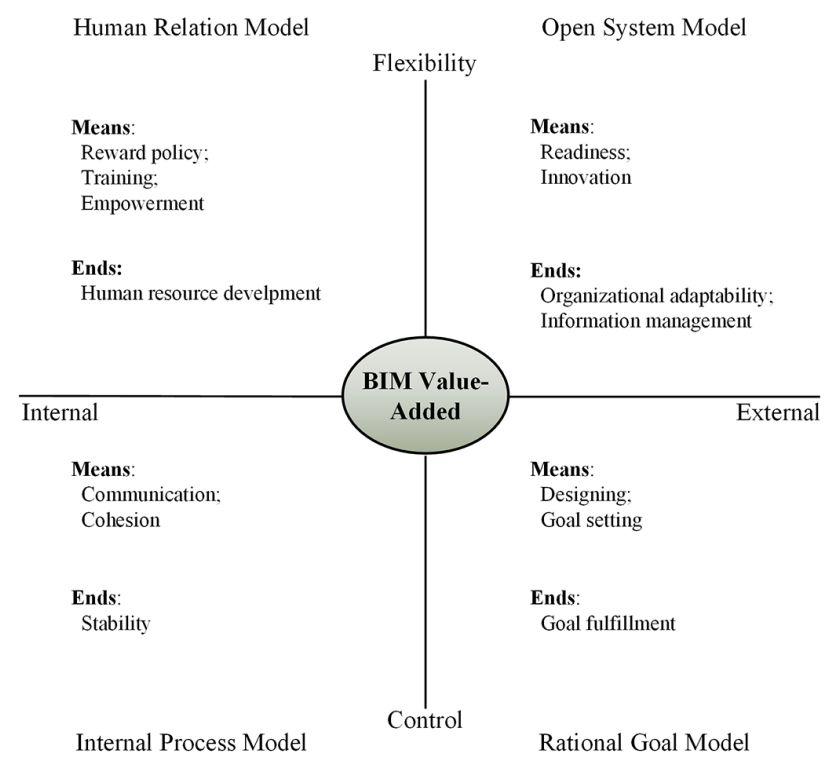

Figure 2. CVA framework for selecting dimensions development) (Hu et al., 2012), participation in decision making (Downey et al., 1975; Li et al., 2013b), and workfamily balance (Ling \& Loo, 2015). Reward orientation, career development, train focus, participation, and autonomy are general climate dimensions that describe the perceived adequate and fair pay practices (Van De Voorde et al., 2010), perceived advancement opportunities (West et al., 1998), perceived human capacities development (Schulte et al., 2009), perceived influence of workers over decisions (Patterson et al., 2005), and perceived reasonable life space (Patterson et al., 2005), respectively. These five dimensions, which are used to measure the satisfaction of workers' needs in some organizations (e.g., financial service firms, university departments, and manufacturing), are also applicable to construction projects. Meanwhile, BIM's implementation requires to satisfy workers' needs, which produces BIM value-added (Song et al., 2017). Organizations undertaking construction projects employ workers from different firms (e.g., construction company, designing institute) that are responsible for the satisfaction of their needs. Furthermore, BIM's implementation improves workers' requirements on satisfaction. For example, many construction projects are asked to adopted BIM, which means existing trainings (i.e. safety training, training for construction professionals) are insufficient to develop workers' BIM capabilities (Ding et al., 2015). Despite the limited budget for BIM training in a construction project, the firms employing a worker still provide opportunities for it to those assigned to the project (Farshchian et al., 2017; Tabassi et al., 2012).

In the internal process model, peer relations and focus on others are the dimensions used to represent the enhancement in relations between workers in construction projects. Relations between workers include relationships among themselves and those between managers and workers (Den Hartog et al., 2013; Eriksson, 2008). Peer relations is a general climate dimension that reflects perceived friendships at equivalent organizational levels (Joyce \& Slocum Jr., 1984). Focus on others is a specific dimension that shows the collective moral climate (Arnaud, 2010). With the advantages of enhancing communication and sharing information, BIM changes relations between workers and reduces opportunistic behaviors in construction projects (Davies \& Harty, 2013; Jin et al., 2018). The peer relations indicating relationship quality (e.g., trust and teamwork) among workers at equivalent organizational levels are enhanced by BIM (Jelodar et al., 2016). Focus on others promoted by BIM illustrates the opposite side of self-interested behavior (Arnaud, 2010; Zheng et al., 2017), representing managers' control of supervising power. It reflects the power structure between managers and workers and supports such relationships (Arnaud, 2010; Wisse et al., 2019).

In the open system model, organizational adaptability and equipment reflect the provision of a stable environment and development of real-time communication among participants, respectively. As a general climate dimension, organizational adaptability reflects workers' 
perceived organizational capacity to adapt quickly to the environment (De Beuckelaer et al., 2007). Equipment reflect workers' perceptions of the appropriate technology to maintain an adequate supply of resources (Beus et al., 2019; Farghaly et al., 2018). Enhanced by BIM, organizational adaptability can promote flexibility under uncertainty, which support establishment of stable environment by managing risks of construction projects (Ganbat et al., 2020; Gil \& Tether, 2011). Furthermore, BIM equipment enables activities or tasks to be visualized in real-time, which can realize BIM value-added through real-time communication (Ibem \& Laryea, 2014; Davidson et al., 2020; Wang et al., 2013).

In the rational goal model, three general climate dimensions - task orientation, hierarchical influence, and goal effectiveness - are chosen to ensure the more accurate pursuit of the objectives of the construction project, thus relieving the litigation mentality of workers, and representing organizational achievement, respectively. Task orientation concerns the perceived monitoring of tasks in an organization (West et al., 1998). Hierarchical influence measures the perceived questioning of authority at different levels of the organizational hierarchy (Koys \& DeCotiis, 1991; Payne \& Mansfield, 1973). Goal effectiveness is used to assess the extent to which the goals have been achieved (Van De Voorde et al., 2010). These three dimensions are also applicable to construction projects. First, with the greater ability to deliver real-time information on activities (Matthews et al., 2015), BIM can support process control (namely task orientation) by inhibiting counter-goal activities of construction project objectives. Second, produced by perceived unfairness of organizational procedures (Bies \& Tyler, 1993), litigation mentality can be relieved by hierarchical influence. With the advantages of allowing quick feedback (Sanguinetti et al., 2012), BIM can strengthen hierarchical influence and provide quicker feedback for unfair procedures by questioning authority. This can supervise the powers of managers, facilitate perceived fairness, enhance workers' trust in them, and contribute to relieving litigation mentality. Third, with the assistance of large database, goal effectiveness is enhanced by BIM and enables the assessment of organizational achievement more accurately in construction projects (Solla et al., 2019).

\section{Methodology}

\subsection{Questionnaire design and survey}

A questionnaire survey is advantageous for (i) exploring the general views of a project's participants on variables and (ii) collecting massive data from a target group (Mohamed, 2002; Romm, 2013). Questionnaires are used widely in construction and management research (Hwang et al., 2018). Therefore, for this study, a questionnaire is an appropriate means of eliciting opinions on the dimensions and indicators of VAO BIM climate. A Chinese questionnaire was developed by the translation/back-translation method, and comprised two sections. The first related to the background and the second aimed at investigating the dimensions and indicators. As recommended in the procedures of Shen et al. (2011), the adequacy and readability of the questionnaire were tested using a pilot study. Six experts, who have had more than five years of practical or academic experience of BIM management in construction projects, were involved in the pilot study to refine and finalize the questionnaire. In order to obtain desired information about VAO BIM climate, the purposive sample, namely construction projects adopting BIM, was chosen. The final questionnaire was distributed to the targeted staff in construction projects from January to February, 2020. A link to the final questionnaire online was sent directly by WeChat to project managers or owners of construction projects, who in turn sent it to their workers. The data were collected by soliciting responses from workers engaged in BIM in construction projects. These workers were asked to complete the questionnaire according to the realities of the construction projects on which they had been working or had just finished. Any worker who knew nothing about BIM was asked to quit the survey. In total, 445 questionnaires were distributed and 306 were returned. According to H. E. A. Tinsley and D. J. Tinsley (1987), samples above 300 show a good generalization. Due to settings of the online survey, all the returned questionnaires were complete without missing data. The sample covered a broad spectrum of location, project type, investment, headcount, major, age, education, job level, BIM experience, frequency to using BIM, and purpose of BIM (see Table 1).

\subsection{Initial indicators of value-added-oriented BIM climate}

\subsubsection{Initial indicators in human relations model}

The dimensions of the VAO BIM climate in the human relations model are reward orientation, career development, participation, train focus, and autonomy. The indicators of reward orientation were designed to measure adequate and fair pay in BIM-related practices. Inspired by pay satisfaction (Van De Voorde et al., 2010) and praise (Rosenthal \& Holmes, 2018), the indicators of reward orientation can be designed as satisfactory pay by focusing on BIM (SPF-BIM), and those of getting praise by focusing on BIM (PF-BIM). The measurement of career development was based on human resource management mentioning growth opportunities, experience management, and career mentoring (Crawshaw \& Game, 2015; Hemmasi et al., 2010; Van Vianen et al., 2018). In the VAO BIM climate, the equivalents can be specified as advancement opportunities due to BIM (AO-BIM), better application experience through BIM (AE-BIM), and better implementation of career goals through BIM (ICG-BIM). In the literature on participation, the indicators used to reflect individuals' influence over decision making are voicing disagreement, sharing decision information, collecting opinions, and communicating with decision makers (Malik \& Wilson, 1995; Patterson et al., 2005). 
Table 1. Background information

\begin{tabular}{|c|c|c|c|c|c|c|c|}
\hline & Measurement & $\mathrm{N}$ & Percentage (\%) & & Measurement & $\mathrm{N}$ & Percentage (\%) \\
\hline \multirow[t]{7}{*}{ Location } & East China & 155 & 50.65 & \multirow[t]{4}{*}{ Major } & Civil engineering & 146 & 47.71 \\
\hline & North China & 30 & 9.8 & & $\begin{array}{l}\text { Electrical and mechanical } \\
\text { engineering }\end{array}$ & 46 & 15.03 \\
\hline & Central China & 17 & 5.56 & & Decoration engineering & 22 & 7.19 \\
\hline & Southern China & 21 & 6.86 & & Others & 92 & 30.07 \\
\hline & Southwest China & 10 & 3.27 & \multirow[t]{4}{*}{ Age } & $20-29$ & 95 & 31.05 \\
\hline & Northwestern China & 69 & 22.55 & & $30-39$ & 126 & 41.18 \\
\hline & Northeastern China & 4 & 1.31 & & $40-49$ & 67 & 21.9 \\
\hline \multirow{5}{*}{$\begin{array}{l}\text { Project } \\
\text { type }\end{array}$} & Building & 136 & 44.44 & & Above 50 & 18 & 5.88 \\
\hline & Tunnel and Bridge & 56 & 18.3 & \multirow[t]{4}{*}{ Education } & Bachelor degree or less & 52 & 16.99 \\
\hline & Railway & 8 & 2.61 & & Undergraduate & 151 & 49.35 \\
\hline & Urban Rail Transit & 15 & 4.9 & & Master & 98 & 32.03 \\
\hline & Others & 91 & 29.74 & & Doctor & 5 & 1.63 \\
\hline \multirow{2}{*}{$\begin{array}{l}\text { Investment } \\
\text { (RMB) }\end{array}$} & $\geq 1$ billion & 85 & 27.78 & \multirow[t]{4}{*}{ Job level } & Top managers & 15 & 4.9 \\
\hline & $<1$ billion & 221 & 72.22 & & Middle managers & 66 & 21.57 \\
\hline \multirow[t]{4}{*}{ Headcount } & Below 50 & 152 & 49.67 & & First-line managers & 96 & 31.37 \\
\hline & $50-99$ & 56 & 18.3 & & Staff & 129 & 42.16 \\
\hline & $100-199$ & 27 & 8.82 & \multirow{4}{*}{$\begin{array}{l}\text { BIM } \\
\text { experience } \\
\text { (years) }\end{array}$} & $\leq 1$ & 186 & 60.78 \\
\hline & Above 200 & 71 & 23.2 & & $1-3$ & 68 & 22.22 \\
\hline \multirow{6}{*}{$\begin{array}{l}\text { Purpose of } \\
\text { BIM }\end{array}$} & Design optimization & 162 & 52.94 & & $3-5$ & 24 & 7.84 \\
\hline & Safety training & 86 & 28.1 & & $>5$ & 28 & 9.15 \\
\hline & Cost management & 132 & 43.14 & \multirow{4}{*}{$\begin{array}{l}\text { Frequency } \\
\text { to using } \\
\text { BIM }\end{array}$} & Frequently & 58 & 18.95 \\
\hline & Document management & 100 & 32.68 & & Occasionally & 166 & 54.25 \\
\hline & Schedule optimization & 113 & 36.93 & & Never & 82 & 26.8 \\
\hline & Others & 109 & 35.62 & & & & \\
\hline
\end{tabular}

In this study, these indicators can be localized as voicing disagreement through BIM (VDT-BIM), sharing decision information through BIM (IST-BIM), better collecting opinions through BIM (COT-BIM), and better communicating with decision makers through BIM (CDMT-BIM). Train focus emphasized quantities (such as adequate training and sufficient training time) and qualities (such as training depth and significance of training) (Kaya et al., 2010; Lim \& Morris, 2006; Schulte et al., 2009). With the application of BIM to training, train focus can be measured by providing adequate BIM training (PA-BIM-T), allocating sufficient time for BIM training (AST-BIM-T), encourage in-depth BIM training (ED-BIM-T), and conducting helpful BIM training (CH-BIM-T). The development of new sets of indicators for autonomy should consider such elements as work activities, work procedures, ways of doing jobs, decisions involved in jobs, and information initiative (Durcikova et al., 2011; Janz, 1999; Lee \& Chen, 2019; Llopis \& Foss, 2016; Patterson et al., 2005). Therefore, this study transforms these elements into scheduling work activities with BIM (SWA-BIM), determining work procedures with BIM (DWP-BIM), seeking the best ways of jobs with BIM (SBW-BIM), making work-related decisions with BIM (MWD-BIM), and owning work-related information initiative with BIM (OWII-BIM).

\subsubsection{Initial indicators in internal process model}

The dimensions of VAO BIM climate in the internal process model were peer relations and focus on others. Originating from relationships in the workplace, and supported by friends and trust, peer relations are measured by indicators involving high-quality relationships (Kaewpan et al., 2017), support from colleagues (Reich \& Benbasat, 1996; Yamasaki \& Nishida, 2009), and trusting colleagues (Parker et al., 1995). When implementing BIM in construction projects, the aforementioned indicators are reflected by obtaining quality of relationships through BIM (OQR-BIM), receiving more colleagues' support through BIM (RCS-BIM), and increasing trust in colleagues (ITCBIM). Considering the two important indicators of a focus on others, namely, sensing responsibility to society and being concerned about collective interests (Arnaud, 2010), sensing more social responsibilities by BIM (SSR-BIM) and paying more attention to collective interests (PACIBIM) are proposed for the VAO BIM climate.

\subsubsection{Initial indicators in open system model}

The dimensions of the VAO BIM climate in the open system model were organizational adaptability and equipment. For organizational adaptability, the indicators should be used to measure organizational capability to 
respond to risks in the work environment (De Beuckelaer et al., 2007), develop simple processes (De Beuckelaer et al., 2007), and to juggle multiple demands (Green et al., 2016). In the VAO BIM climate, these indicators should cover the role of BIM. Therefore, three indicators were designed as a quicker response to environmental risks with BIM (QRER-BIM), simplifying process with BIM (SP-BIM), and satisfying multiple demands with BIM (SMD-BIM). In light the perspective of safety, indicators of equipment should cover sufficient quantity, availability, being free of faults, platform, and guidelines (Beus et al., 2019; Colley \& Neal, 2012; Mosher et al., 2012). Therefore, the indicators that can measure equipment can be designed as follows: sufficient BIM equipment (SE-BIM), availability of BIM equipment (AOE-BIM), being free of faults (FF-BIM), supported by a BIM system (SS-BIM), and detailed BIM guidelines (DG-BIM).

\subsubsection{Initial indicators in rational goal model}

The dimensions of the VAO BIM climate in the rational goal model were task orientation, hierarchical influence, and goal effectiveness. Task orientation was measured using four items: department monitoring through BIM (DM-BIM), work innovation through BIM (WI-BIM), learning from each other through BIM (LEO-BIM), and understanding task criteria with BIM (UTC-BIM). From the perspectives of the department and the team, these items combined with BIM assess departmental monitoring (West et al., 1998), individual innovation (Hülsheger et al., 2009), building on each other's ideas (Kivimaki \& Elovainio, 1999), and criteria for tasks (Kivimäki et al., 1997). Two items measuring hierarchical influence were documenting power and responsibility with BIM (DPR$\mathrm{BIM}$ ), and perceiving less authoritarian (PLA-BIM). These items measuring the extent of perceived authoritarianism and the records of authoritative positions were mined from safety compliance and business, respectively (Dahl \& Olsen, 2013; Payne \& Mansfield, 1973). Two items measuring the level of goal effectiveness were the better achievement of goals with BIM (BAG-BIM) and timely accomplishing tasks with BIM (TAT-BIM). Adapted from Van De Voorde et al. (2010) and Pearce and Sims Jr. (2002), these items enabled us to describe the extent to which goals were achieved and tasks were accomplished on time. The indicators of the VAO BIM climate are presented in Table 2, all of which were measured on a fivepoint Likert scale.

\subsection{Analytic strategy}

Two approaches are used to test the dimensions and indicators. First, the reliabilities of the 12 dimensions of the VAO BIM climate are validated using Cronbach's Alphas in the SPSS 23 software package. Second, the confirmatory factor analysis (CFA) in the AMOS 21 software is used to examine whether the proposed dimensions and indicators fit the empirical data.

As recommended in the context of scale development, CFA is a powerful tool for testing the stability of the struc- ture of the factor and providing improved information for the given measures (Hinkin, 1995). Given the objective of this study, it was reasonable to use CFA, which is driven by the theoretical relationships between observed and unobserved variables (Yuan et al., 2018). Theoretical analysis was used to establish a priori model that comprised the observed variables, the unobserved variables, and theoretical correlations among the variables. Good fits between the theoretical correlations and the empirical correlations computed from empirical data would confirm the accuracies of the theoretical correlations and the usefulness of the priori model (Hemmelgarn et al., 1995). In this study, the observed variables are the indicators of VAO BIM climate and the unobserved variables are its dimensions. The corresponding relationships among the indicators, dimensions, and the VAO BIM climate constitute the theoretical correlations. Thus, the proposed indicators and dimensions can be verified by CFA.

\section{Results}

\subsection{Reliability testing}

The internal consistency of the data collected from the questionnaires was tested by reliability analysis. Cronbach's Alphas are the basis for judging internal consistency (Olanipekun et al., 2018). As recommended by Yuan et al. (2018), values of Cronbach's Alphas exceeding 0.9, between 0.9 and 0.7 , between 0.7 and 0.6 , between 0.6 and 0.5 , and lower than 0.5 represent excellent, good, acceptable, poor, and unacceptable reliability, respectively. The values of Cronbach's Alphas for all the indicators is 0.990, and the values for reward orientation, career development, participation, train focus, autonomy, organizational adaptability, equipment, task orientation, hierarchical influence, and goal effectiveness are $0.863,0.906,0.946,0.908,0.959,0.944$, $0.935,0.923,0.943,0.948,0.925$, and 0.930 , respectively.

\subsection{Validity testing}

Discriminant and convergent validities aim to assess the extent to which the dimensions are uncorrelated and related, respectively (Lievens et al., 2006). In this study, discriminant validity helps identify whether it is appropriate to distinguish one, four, or 12 variables. Convergent validity describes the contribution of each dimension to the VAO BIM climate.

Discriminant validity can be examined using the CFA in AMOS 21. The results show that the 12-variable model fits to the data reasonably $\left(\chi^{2}=816.807, \mathrm{p}<0.001\right.$, Df $=$ $459, \mathrm{CFI}=0.980, \mathrm{TLI}=0.968 ; \mathrm{SRMR}=0.029 ; \mathrm{RMSEA}=$ 0.051) (Browne \& Cudeck, 1992; Hu \& Bentler, 1999), better than do the four-variable model established according to the four sections of the CVA framework $\left(\chi^{2}=1890.933\right.$, $\mathrm{p}<0.001, \mathrm{Df}=595, \mathrm{CFI}=0.928, \mathrm{TLI}=0.910 ; \mathrm{SRMR}=$ 0.041 ; RMSEA $=0.085$ ); and the one-variable model, which collapses all of variables $\left(\chi^{2}=1377.493, \mathrm{p}<0.001, \mathrm{Df}=\right.$ $506, \mathrm{CFI}=0.952, \mathrm{TLI}=0.929$; $\mathrm{SRMR}=0.034$; RMSEA $=$ 0.075). 
Table 2. Indicators of value-added oriented BIM climate

\begin{tabular}{|c|c|c|c|c|}
\hline Sections & Dimensions & Indicators & Abbr. & References \\
\hline \multirow{18}{*}{$\begin{array}{l}\text { Human } \\
\text { relations } \\
\text { model }\end{array}$} & \multirow[t]{2}{*}{$\begin{array}{l}\text { Reward } \\
\text { orientation }\end{array}$} & Satisfactory pay by focusing on BIM & SPF-BIM & $\begin{array}{l}\text { Van De Voorde et al. } \\
(2010)\end{array}$ \\
\hline & & Getting praise by focusing on BIM & PF-BIM & $\begin{array}{l}\text { Rosenthal and Holmes } \\
(2018)\end{array}$ \\
\hline & \multirow[t]{3}{*}{$\begin{array}{l}\text { Career } \\
\text { development }\end{array}$} & Advancement opportunities due to BIM & AO-BIM & $\begin{array}{l}\text { Crawshaw and Game } \\
(2015)\end{array}$ \\
\hline & & Better application experience through BIM & AE-BIM & Hemmasi et al. (2010) \\
\hline & & Better implementation of career goals through BIM & ICG-BIM & Van Vianen et al. (2018) \\
\hline & \multirow[t]{4}{*}{ Participation } & Voicing disagreement through BIM & VDT-BIM & Malik and Wilson (1995) \\
\hline & & Sharing decision information through BIM & IST-BIM & Patterson et al. (2005) \\
\hline & & Better collecting opinions through BIM & COT-BIM & Patterson et al. (2005) \\
\hline & & Better communicating with decision makers through BIM & CDMT-BIM & Patterson et al. (2005) \\
\hline & \multirow[t]{4}{*}{ Train focus } & Providing adequate BIM training & PA-BIM-T & Schulte et al. (2009) \\
\hline & & Allocating sufficient time for BIM training & AST-BIM-T & Kaya et al. (2010) \\
\hline & & Encourage in depth BIM training & ED-BIM-T & Kaya et al. (2010) \\
\hline & & Conducting helpful BIM training & CH-BIM-T & Lim and Morris (2006) \\
\hline & \multirow[t]{5}{*}{ Autonomy } & Scheduling work activities with BIM & SWA-BIM & Durcikova et al. (2011) \\
\hline & & Determining work procedures with BIM & DWP-BIM & Durcikova et al. (2011) \\
\hline & & Seeking the best ways of jobs with BIM & SBW-BIM & Lee and Chen (2019) \\
\hline & & Making work-related decisions with BIM & MWD-BIM & Patterson et al. (2005) \\
\hline & & Owning work-related information initiative with BIM & OWII-BIM & $\begin{array}{l}\text { Janz (1999), Llopis and } \\
\text { Foss (2016) }\end{array}$ \\
\hline \multirow{5}{*}{$\begin{array}{l}\text { Internal } \\
\text { process } \\
\text { model }\end{array}$} & \multirow[t]{3}{*}{ Peer relations } & Obtaining quality of relationships through BIM & OQR-BIM & Kaewpan et al. (2017) \\
\hline & & Receiving more colleagues' support through BIM & RCS-BIM & $\begin{array}{l}\text { Reich and Benbasat } \\
\text { (1996), Yamasaki and } \\
\text { Nishida (2009) }\end{array}$ \\
\hline & & Increasing trusts in colleagues & ITC-BIM & Parker et al. (1995) \\
\hline & \multirow{2}{*}{$\begin{array}{l}\text { Focus on } \\
\text { Others }\end{array}$} & Sensing more social responsibilities by BIM & SSR-BIM & Arnaud (2010) \\
\hline & & Paying more attention to collective interests & PACI-BIM & Arnaud (2010) \\
\hline \multirow{8}{*}{$\begin{array}{l}\text { Open } \\
\text { system } \\
\text { model }\end{array}$} & \multirow[t]{3}{*}{$\begin{array}{l}\text { Organizational } \\
\text { adaptability }\end{array}$} & Quicker response to environmental risks with BIM & QRER-BIM & $\begin{array}{l}\text { De Beuckelaer et al. } \\
(2007)\end{array}$ \\
\hline & & Simplifying process with BIM & SP-BIM & $\begin{array}{l}\text { De Beuckelaer et al. } \\
(2007)\end{array}$ \\
\hline & & Satisfying multiple demands with BIM & SMD-BIM & Green et al. (2016) \\
\hline & \multirow[t]{5}{*}{ Equipment } & Sufficient BIM equipment & SE-BIM & Beus et al. (2019) \\
\hline & & Availability of BIM equipment & AOE-BIM & Mosher et al. (2012) \\
\hline & & Free of faults & FF-BIM & Beus et al. (2019) \\
\hline & & Supported by a BIM system & SS-BIM & Colley and Neal (2012) \\
\hline & & Detailed BIM guidelines & DG-BIM & Colley and Neal (2012) \\
\hline \multirow{8}{*}{$\begin{array}{l}\text { Rational } \\
\text { goal } \\
\text { model }\end{array}$} & \multirow{4}{*}{\begin{tabular}{|l|} 
Task \\
orientation
\end{tabular}} & Department monitoring through BIM & DM-BIM & West et al. (1998) \\
\hline & & Work innovation through BIM & WI-BIM & Hülsheger et al. (2009) \\
\hline & & Learning from each other through BIM & LEO-BIM & $\begin{array}{l}\text { Kivimaki and Elovainio } \\
\text { (1999) }\end{array}$ \\
\hline & & Understanding task criteria with BIM & UTC-BIM & Kivimäki et al. (1997) \\
\hline & \multirow{2}{*}{$\begin{array}{l}\text { Hierarchical } \\
\text { influence }\end{array}$} & Documenting power and responsibility with BIM & DPR-BIM & Dahl and Olsen (2013) \\
\hline & & Perceiving less authoritarian & PLA-BIM & $\begin{array}{l}\text { Payne and Mansfield } \\
\text { (1973) }\end{array}$ \\
\hline & \multirow[t]{2}{*}{$\begin{array}{l}\text { Goal } \\
\text { effectiveness }\end{array}$} & Better achievement of goals with BIM & BAG-BIM & $\begin{array}{l}\text { Van De Voorde et al. } \\
(2010)\end{array}$ \\
\hline & & Timely accomplishing task with BIM & TAT-BIM & Pearce and Sims Jr. (2002) \\
\hline
\end{tabular}


The average variance extracted (AVE) was used to assess convergent validity, and not until the AVE exceeded the threshold value $(0.50)$ was convergent validity satisfied (Garbarino \& Johnson, 1999). The results indicated that the AVE for reward orientation, career development, participation, train focus, autonomy, peer relations, focus on others, organizational adaptability, equipment, task orientation, hierarchical influence, and goal effectiveness were $0.774,0.763,0.816,0.697,0.824,0.846,0.872,0.837,0.771$, $0.818,0.850,0.872$, respectively.

\subsection{Ranking of value-added-oriented BIM climate indicators}

The indicators of VAO BIM climate were ranked according to their mean values, with a higher mean value indicating a higher rank (Yang et al., 2010). Tables 3 and 4 give the rankings of the indicators and rankings in different dimensions, respectively.

As listed in Table 3, the mean values of the 39 indicators exceed 3.00 and range from a maximum of 3.56 (CDMT-BIM) to a minimum of 3.04 (AST-BIM-T). These indicate that all the indicators are critical for the VAO BIM climate. The 10 highest-ranked indicators are CDMTBIM, CH-BIM-T, IST-BIM, BAG-BIM, LEO-BIM, COTBIM, UTC-BIM, TAT-BIM, RCS-BIM, and WI-BIM. Note that seven of the top 10 indicators belong to participation, task orientation, and goal effectiveness, respectively. The least-important indicator is AST-BIM-T.

As mentioned in the subsection entitled "Initial indicators of value-added-oriented BIM climate", all indicators of the VAO BIM climate were assigned to one of the $12 \mathrm{di}$ mensions. Table 4 gives the ranking in different dimensions.

Table 4 shows that the mean values for the indicators in different dimensions are greater than 3.00, indicating that these indicators are important to the VAO BIM climate dimensions. The following are some important findings: in reward orientation, PF-BIM is more important than SPF-BIM; in career development, AE-BIM and ICG-
BIM are equally important; in participation, CDMT-BIM is the core elements. The highest score of $\mathrm{CH}-\mathrm{BIM}-\mathrm{T}$ in train focus suggests the primary concerns of training. In autonomy, MWD-BIM plays the most important role to let individual perceive reasonable life spaces. RCS-BIM contributes more to peer relations than do the other indicators in this dimension. In focus on others, PACI-BIM is more important in providing a stable environment. SMD-BIM is a significant indicator to support individuals' perceptions of organizational capacity to quickly adapt to environment. AOE-BIM is ranked relative highly as an indicator in equipment. LEO-BIM, PLA-BIM, and BAGBIM are emphasized most highly in task orientation, hierarchical influence, and goal effectiveness, respectively.

\subsection{Results of confirmatory factor analysis (CFA)}

As mentioned in the subsection entitled "Analytic strategy", CFA was performed in AMOS 21 to test the proposed dimensions and indicators of the VAO BIM climate. Furthermore, the relationships between the VAO BIM climate and the dimensions, and between the dimensions and indicators were examined. The results of CFA are shown in Figure 3.

The straight lines from VAO BIM climate to dimensions, and from dimensions to indicators indicate the respective relationships; the numbers on these straight lines represent the factor loadings of the relationships. The results of CFA show that high factor loadings are obtained in the relationships between VAO BIM climate $(>0.899)$ and 12 dimensions, and between dimensions and indicators $(>0.766)$. All the factor loadings are statistically significant at the 0.001 level. Furthermore, compared to the fitting indices $\left(1<=\chi^{2} / \mathrm{Df}<=5,0.90<=\mathrm{CFI}\right.$, RMSEA $<=$ $0.06)$, the established CFA framework fits the data reasonably $\left(\chi^{2} / \mathrm{Df}=3.646, \mathrm{CFI}=0.906, \mathrm{RMSEA}=0.046\right)(\mathrm{Hu} \&$ Bentler, 1999; Yuan et al., 2018). Therefore, the proposed dimensions and indicators are reasonable, and can be used in the subsequent analyses.

Table 3. Ranking of the indicators

\begin{tabular}{|l|c|c|l|c|c|l|c|c|}
\hline \multicolumn{1}{|c|}{ Indicators } & Mean & Rank & \multicolumn{1}{|c|}{ Indicators } & Mean & Rank & Indicators & Mean & Rank \\
\hline SPF-BIM & 3.16 & 37 & SWA-BIM & 3.41 & 25 & SE-BIM & 3.25 & 36 \\
\hline PF-BIM & 3.36 & 29 & DWP-BIM & 3.37 & 28 & AOE-BIM & 3.47 & 14 \\
\hline AO-BIM & 3.30 & 33 & SBW-BIM & 3.42 & 21 & FF-BIM & 3.26 & 35 \\
\hline AE-BIM & 3.48 & 11 & MWD-BIM & 3.43 & 19 & SS-BIM & 3.36 & 29 \\
\hline ICG-BIM & 3.48 & 11 & OWII-BIM & 3.42 & 21 & DG-BIM & 3.28 & 34 \\
\hline VDT-BIM & 3.45 & 17 & OQR-BIM & 3.42 & 21 & DM-BIM & 3.32 & 32 \\
\hline IST-BIM & 3.52 & 3 & RCS-BIM & 3.49 & 9 & WI-BIM & 3.49 & 9 \\
\hline COT-BIM & 3.50 & 6 & ITC-BIM & 3.44 & 18 & LEO-BIM & 3.51 & 5 \\
\hline CDMT-BIM & 3.56 & 1 & SSR-BIM & 3.46 & 16 & UTC-BIM & 3.50 & 6 \\
\hline PA-BIM-T & 3.15 & 38 & PACI-BIM & 3.48 & 11 & DPR-BIM & 3.38 & 27 \\
\hline AST-BIM-T & 3.04 & 39 & QRER-BIM & 3.43 & 19 & PLA-BIM & 3.41 & 25 \\
\hline ED-BIM-T & 3.33 & 31 & SP-BIM & 3.42 & 21 & BAG-BIM & 3.52 & 3 \\
\hline CH-BIM-T & 3.53 & 2 & SMD-BIM & 3.47 & 14 & TAT-BIM & 3.50 & 6 \\
\hline
\end{tabular}


Table 4. Ranking in different dimensions

\begin{tabular}{|c|c|c|c|c|c|c|c|c|c|c|c|}
\hline \multicolumn{3}{|c|}{ Reward orientation } & \multicolumn{3}{|c|}{ Career development } & \multicolumn{3}{|c|}{ Participation } & \multicolumn{3}{|c|}{ Train focus } \\
\hline Rank & Indicators & Mean & Rank & Indicators & Mean & Rank & Indicators & Mean & Rank & Indicators & Mean \\
\hline 2 & SPF-BIM & 3.16 & 3 & AO-BIM & 3.30 & 4 & VDT-BIM & 3.45 & 3 & PA-BIM-T & 3.15 \\
\hline \multirow[t]{3}{*}{1} & PF-BIM & 3.36 & 1 & AE-BIM & 3.48 & 2 & IST-BIM & 3.52 & 4 & AST-BIM-T & 3.04 \\
\hline & & & 1 & ICG-BIM & 3.48 & 3 & COT-BIM & 3.50 & 2 & ED-BIM-T & 3.33 \\
\hline & & & & & & 1 & CDMT-BIM & 3.56 & 1 & CH-BIM-T & 3.53 \\
\hline \multicolumn{3}{|c|}{ Autonomy } & \multicolumn{3}{|c|}{ Peer relations } & \multicolumn{3}{|c|}{ Focus on others } & \multicolumn{3}{|c|}{ Organizational adaptability } \\
\hline Rank & Indicators & Mean & Rank & \begin{tabular}{|l|} 
Indicators \\
\end{tabular} & Mean & Rank & Indicators & Mean & Rank & Indicators & Mean \\
\hline 4 & SWA-BIM & 3.41 & 3 & OQR-BIM & 3.42 & 2 & SSR-BIM & 3.46 & 2 & QRER-BIM & 3.43 \\
\hline 5 & DWP-BIM & 3.37 & 1 & RCS-BIM & 3.49 & 1 & PACI-BIM & 3.48 & 3 & SP-BIM & 3.42 \\
\hline 2 & SBW-BIM & 3.42 & 2 & ITC-BIM & 3.44 & & & & 1 & SMD-BIM & 3.47 \\
\hline 1 & MWD-BIM & 3.43 & & & & & & & & & \\
\hline 2 & OWII-BIM & 3.42 & & & & & & & & & \\
\hline \multicolumn{3}{|c|}{ Equipment } & \multicolumn{3}{|c|}{ Task orientation } & \multicolumn{3}{|c|}{ Hierarchical influence } & \multicolumn{3}{|c|}{ Goal effectiveness } \\
\hline Rank & Indicators & Mean & Rank & Indicators & Mean & Rank & Indicators & Mean & Rank & Indicators & Mean \\
\hline 5 & SE-BIM & 3.25 & 4 & DM-BIM & 3.32 & 2 & DPR-BIM & 3.38 & 1 & BAG-BIM & 3.52 \\
\hline 1 & AOE-BIM & 3.47 & 3 & WI-BIM & 3.49 & 1 & PLA-BIM & 3.41 & 2 & TAT-BIM & 3.50 \\
\hline 4 & FF-BIM & 3.26 & 1 & LEO-BIM & 3.51 & & & & & & \\
\hline 2 & SS-BIM & 3.36 & 2 & UTC-BIM & 3.50 & & & & & & \\
\hline 3 & DG-BIM & 3.28 & & & & & & & & & \\
\hline
\end{tabular}

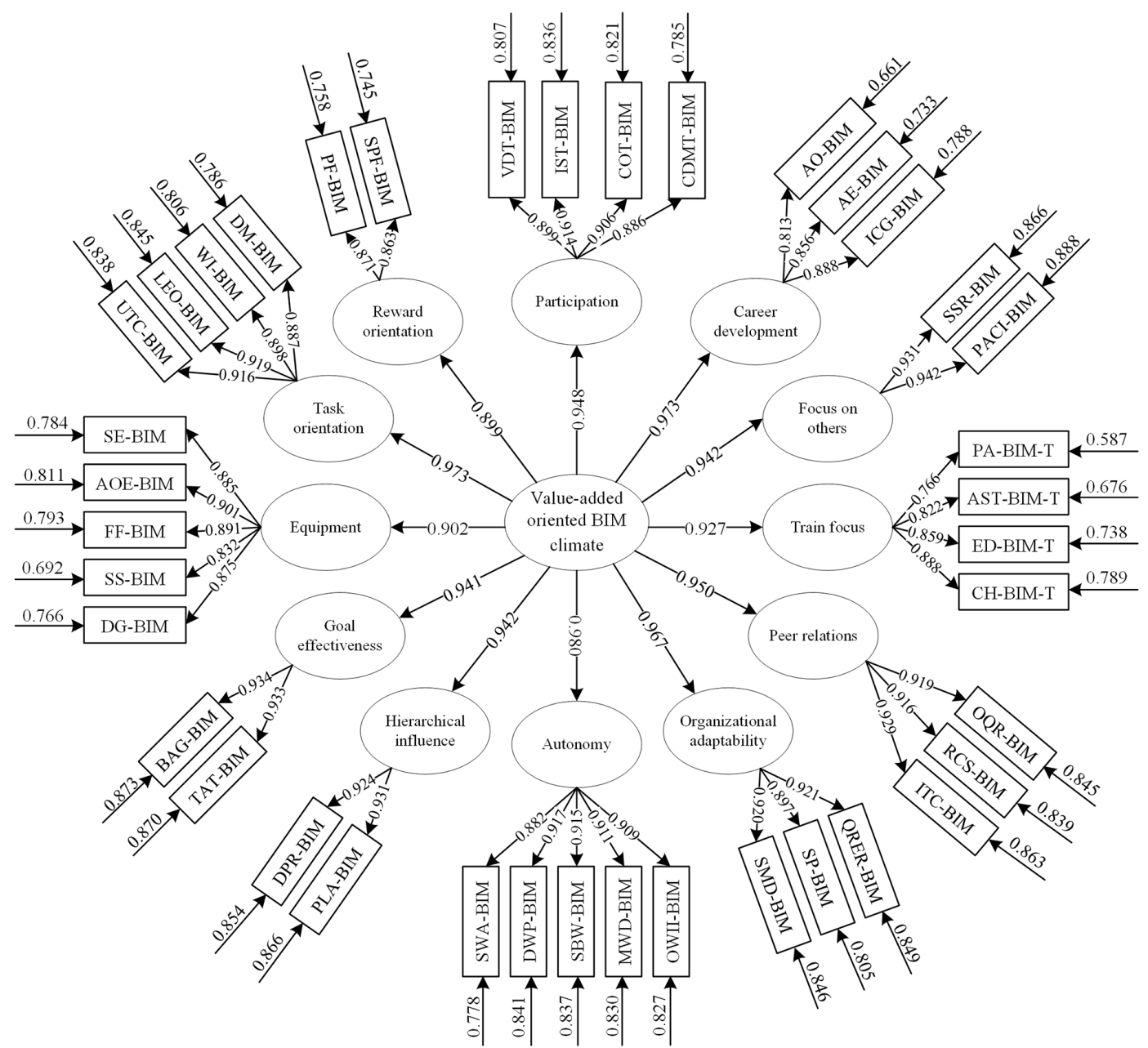

Figure 3. Results of CFA 


\section{Discussion}

\subsection{Dimensions of value-added-oriented BIM climate}

This study selects and validates the dimensions of the VAO BIM climate in the context of construction projects. The dimensions of reward orientation, career development, participation, train focus, autonomy, peer relations, focus on others, organizational adaptability, equipment, task orientation, hierarchical influence, and goal effectiveness are found to be both reliable and valid. Different from the perceived benefits, challenges, and risks in the BIM climate in Shanghai and Wenzhou, as proposed by Xu et al. (2018), this study focuses on value-added in construction projects and extends the BIM climate to a nationwide perspective. Rather than emphasizing communication and cooperation in large-scale projects (Hannevik et al., 2014), the VAO BIM climate pays more attention to autonomy, career development, and task orientation. The finding explores the core dimensions of the understanding of human-BIM interactions and drives organizations undertaking construction project to implement BIM. The finding indicates that the significance of BIM in reflecting value-added embodies a reasonable life space, advancement opportunities, and organizational willingness engaged in the monitoring process. Moreover, distinguishing from the important role played by fair reward in politics (Parker et al., 1995), reward orientation received relatively little attention in the VAO BIM climate. This finding further operationalizes reward orientation in the context of BIM-enabled construction projects, enriches the understanding of the fairness of reward brought by BIM, and demonstrates the role of reward orientation in predicting the VAO BIM climate.

\subsection{Indicators of value-added-oriented BIM climate}

To measure the dimensions of the VAO BIM climate, the corresponding indicators were designed and tested in construction projects. The results show that the 39 indicators present a good fit for reliability and validity requirements. Compared with organizational climate indicators proposed in some industries (González-Romá et al., 2009; Patterson et al., 2005), these results provide a comprehensive list of indicators for measuring the VAO BIM climate in the construction industry. Table 3 shows that the top 10 indicators belong mainly to three dimensions: participation, task orientation, and goal effectiveness. The finding operationalizes BIM value in joint participation, task performance, and improvement in project outcomes (Wu \& Issa, 2015; Wu et al., 2018; Zhang et al., 2017). The importance of workers' involvement in decision making to establish an organizational climate as proposed by Kwon et al. (2016) is elaborated empirically in the context of construction projects by the highest rank of better communicating with decision makers through BIM (CDMT-BIM). By contrast, the lowest rank of AST-BIM-T indicates that the critical role of allocating sufficient time for BIM training is yet to be realized clearly, which offers a specific context in which to understand the extensive training proposed by Kaya et al. (2010). Additionally, the factor loadings in Figure 3 describe the core indicators in each dimension. Nevertheless, comparing Table 4 with Figure 3, the ranking in different dimensions cannot support the understanding of these core indicators. For instance, the highest scores in participation, autonomy, peer relations, and organizational adaptability are MWD-BIM, RCS-BIM, CDMT-BIM, and SMD-BIM, respectively, but these factor loadings are not the highest in these dimensions. Thus, misunderstandings persist regarding the core indicators, which may result in resources being allocated in the inappropriate directions. Distinct from the study by Xu et al. (2018), the misunderstandings found here represent the cognitive biases in BIM-enabled construction projects.

\subsection{Theoretical implication}

The dimensions and indicators of VAO BIM climate make several contributions to the BIM climate literature. First, the dimensions and indicators can contribute to resource allocation in construction project management. According to Grabowski et al. (2016), absent reasonable data brings difficulties to resource allocation. In this study, the data challenge supporting resource allocation for BIM valueadded is addressed by the indicators list. The dimensions and indicators assessing the VAO BIM climate can help collect appropriate data that reflects BIM value-added in construction projects. Then, the data is used to establish resource allocation models that support assigning resources to tasks and creating VAO BIM climate in construction projects. Second, the dimensions and indicators provide a framework for participants of construction projects to shape the salience and meaning of BIM. Poirier et al. (2017) developed five cognitive determinants to understand BIM-enabled collaboration which produces BIM value in construction projects. In this study, these cognitive determinants are enriched with regard to individual perceived BIM value-added. This finding can improve individuals' cognition on BIM and treat BIM as a way to realize value-added rather than an information tool alone. Third, the dimensions and indicators help enhance the understanding of human-BIM interactions in construction projects. The difficulty that participants access BIM determines the interaction frequency with BIM (Mehrbod et al., 2019). In this study, the difficulty is reduced by increasing multiple channels to connect with BIM. For example, train focus, autonomy, and participation provide more clues to apply BIM, which can create more opportunities for individuals to interact with BIM and to understand human-BIM interactions. Fourth, the dimensions and indicators are critical to building cumulative knowledge in BIM-enabled construction projects. As reported by MacKenzie et al. (2011), the failure to define adequate constructs and indictors can result in incomplete knowledge absorption. In this study, the verified dimen- 
sions and indicators can support to identify and capture knowledge about BIM value-added in construction projects. Fifth, the dimensions and indicators empirically test the importance of the non-technical perspective in BIM adoption decision framework. Gu and London (2010) proposed that the focus of the decision framework incline to technical requirement cannot fully support BIM adoption, and the non-technical perspective has to be concerned early. In this study, the non-technical perspective in decision framework of BIM adoption is realized by individual perception of BIM value-added.

\subsection{Practical implication}

The dimensions and indicators of VAO BIM climate can also provide some suggestions for managers in construction projects. First, project managers can apply the indicator list VAO BIM climate as a diagnostic tool to assess VAO BIM climate and to find weakness of the climate, which can support the enhancement of the climate. For example, practical measures may include establishing BIM incentive policies, participatory decision-making policies, early-stage communication policies and experiential train policies to create or maintain VAO BIM climate in construction projects. Second, the three core dimensions including autonomy, career development, and task orientation can be treated as the breakthrough to strengthen workers' perception of BIM value-added. Managers in BIM-enable construction projects can identify unfixed interdepend tasks, and empower workers making their own plans or schedules, determining their working hours and workplaces, etc. Meanwhile, some measures, such as setting BIM positions, designing BIM promotion assessment indicators, and so forth, can provide recommendations for project managers to create more advancement opportunities. In order to enhance organizational willingness engaged in the monitoring process, it is necessary for project managers to advance BIM platform. This advancement aims to improve accuracy of process monitor and optimize the ways organizations access to process monitor. Depending on Big Data, Artificial Intelligence, and BIM visualization, a real-time monitor subsystem including process data collection, process analysis, and process outcomes display can be developed to support passive process monitor. Third, the top 10 indicators hold practical implications for managers by showing workers' interests on BIM application. For example, practical measures may include establishing cross-hierarchy communication methods and optional course database to lessen workers' resistance to BIM. Fourth, the four misunderstood indicators show the place where correcting strategies act, which can help integrate BIM with existing process of construction projects management. Strategies, such as replacing repeated tasks, optimizing the logic of tasks, and developing risk-alert subsystem, can be proposed to enhance BIM application in existing process.

\section{Conclusions and limitations}

This study explored the dimensions and indicator list of the VAO BIM climate in construction projects. The proposed dimensions and indicators were found to both good reliable and valid, with autonomy, career development, and task orientation affecting the VAO BIM climate most significantly, and reward orientation playing a relatively weak role. The top 10 indicators were CDMT-BIM, CH-BIM-T, IST-BIM, BAG-BIM, LEO-BIM, COT-BIM, UTC-BIM, TAT-BIM, RCS-BIM, and WI-BIM, with ASTBIM-T yielding the lowest mean value of 39 indicators. In addition, this study showed that workers paid attention to the indicators that they should not have. Due to the BIM movement which encourages to establish various BIM policies and develop different BIM technologies in China (Xu et al., 2018), more common and representative challenges emerge in the management of BIM. Thus, the contribution of these results has implications worldwide, not only in one country. Specifically, these findings provide a useful tool for managers to evaluate the VAO BIM climate in a construction project, and also (i) help managers identify weaknesses in the establishment and maintenance of the VAO BIM climate, (ii) make workers recognize the value-added of BIM, (iii) enhance workers' acceptance of BIM, and (iv) support the integration of BIM in current process of construction project management. More importantly, the theoretically established and empirically demonstrated dimensions and indicator list can (i) guide reasonable resource allocation in construction project management, (ii) help shape the salience and meaning of BIM for participants of construction projects, (iii) facilitate the understanding of human-BIM interactions in construction projects, (iv) contribute to the BIM knowledge system, and (v) improve decision framework of BIM adoption in construction projects.

Despite its contributions, this study has some limitations. First, because BIM practice began in most firms only toward the end of 2014, BIM practice in construction projects remains in its exploratory stage. Thus, few workers had more than two years of BIM experience, and more research is needed to confirm the findings of this study. Second, although this study provided some useful findings, the relationships among the dimensions of the VAO BIM climate were not analyzed, and more work is required to expand beyond this region. Third, due to the purpose of this study, this study focused on clarification of the dimensions and indicator list of the VAO BIM climate, and little attention was given to the relationship between VAO BIM climate and construction project performance. Thus, more delicate research designs should be conducted to explore the relationship. In addition, this study analyzed the relationship between BIM climate and construction project performance qualitatively. However, the relationship should be validated quantitatively through future research. 


\section{Acknowledgements}

The authors gratefully acknowledge all survey participants and reviewers of the paper, and financial support from the National Natural Science Foundation, China (NSFC-71671042, 71472037); the National Key Research and Development program (2016YFC0702001-06); the Social Science Foundation of China (14AJY013); the Research Foundation of Humanities and Social Sciences of Ministry of China (20YJCZH183); and the Fundamental Research Funds for the Central Universities, China, for financially supporting this research.

\section{Funding}

This work was supported by the $<$ National Natural Science Foundation, China $>$ under Grant [number 71671042]; $<$ National Natural Science Foundation, China $>$ under Grant [number 71472037]; < National Key Research and Development program> under Grant [number 2016YFC0702001-06]; <Social Science Foundation of China $>$ under Grant [number 14AJY013]; and $<$ Research Foundation of Humanities and Social Sciences of Ministry of China> under Grant [number 20YJCZH183].

\section{Author contributions}

Lei Zhang, Jingfeng Yuan, and Mirosław J. Skibniewski conceived the study and were responsible for the design and development of the data analysis. Lei Zhang, Jingfeng Yuan, Yan Ning, and Junwei Ma were responsible for data collection and analysis. Lei Zhang, Jingfeng Yuan, and Nini Xia were responsible for data interpretation. Lei Zhang wrote the first draft of the article.

\section{Disclosure statement}

Neither of the authors has any competing financial, professional, or personal interests from other parties.

\section{References}

Allen, D. G., Shore, L. M., \& Griffeth, R. W. (2003). The role of perceived organizational support and supportive human resource practices in the turnover process. Journal of Management, 29(1), 99-118.

https://doi.org/10.1177/014920630302900107

Almuntaser, T., Sanni-Anibire Muizz, O., \& Hassanain Mohammad, A. (2018). Adoption and implementation of BIM - case study of a Saudi Arabian AEC firm. International Journal of Managing Projects in Business, 11(3), 608-624. https://doi.org/10.1108/IJMPB-05-2017-0046

Alreemy, Z., Chang, V., Walters, R., \& Wills, G. (2016). Critical success factors (CSFs) for information technology governance (ITG). International Journal of Information Management, 36(6), 907-916.

https://doi.org/10.1016/j.ijinfomgt.2016.05.017

Alruqi, W. M., Hallowell, M. R., \& Techera, U. (2018). Safety climate dimensions and their relationship to construction safety performance: A meta-analytic review. Safety Science, 109, 165-173. https://doi.org/10.1016/j.ssci.2018.05.019
Araten-Bergman, T. (2016). Managers' hiring intentions and the actual hiring of qualified workers with disabilities. The International Journal of Human Resource Management, 27(14), 1510-1530. https://doi.org/10.1080/09585192.2015.1128466

Arnaud, A. (2010). Conceptualizing and measuring ethical work climate: Development and validation of the ethical climate index. Business \& Society, 49(2), 345-358.

https://doi.org/10.1177/0007650310362865

Barrick, M. R., Bradley, B. H., Kristof-Brown, A. L., \& Colbert, A. E. (2007). The moderating role of top management team interdependence: Implications for real teams and working groups. Academy of Management Journal, 50(3), 544-557. https://doi.org/10.5465/amj.2007.25525781

Beus, J. M., Jarrett, S. M., Bergman, M. E., \& Payne, S. C. (2012). Perceptual equivalence of psychological climates within groups: When agreement indices do not agree. Journal of Occupational and Organizational Psychology, 85(3), 454-471. https://doi.org/10.1111/j.2044-8325.2011.02049.x

Beus, J. M., Payne, S. C., Arthur Jr, W., \& Muñoz, G. J. (2019). The development and validation of a cross-industry safety climate measure: resolving conceptual and operational issues. Journal of Management, 45(5), 1987-2013. https://doi.org/10.1177/0149206317745596

Bies, R. J., \& Tyler, T. R. (1993). The "litigation mentality" in organizations: A test of alternative psychological explanations. Organization Science, 4(3), 352-366.

https://doi.org/10.1287/orsc.4.3.352

Bostrom, R. P., \& Heinen, J. S. (1977a). MIS problems and failures: A socio-technical perspective. Part I: The causes. MIS Quarterly, 1(3), 17-32. https://doi.org/10.2307/248710

Bostrom, R. P., \& Heinen, J. S. (1977b). MIS problems and failures: a socio-technical perspective, part II: the application of socio-technical theory. MIS Quarterly, 1(4), 11-28. https://doi.org/10.2307/249019

Browne, M. W., \& Cudeck, R. (1992). Alternative ways of assessing model fit. Sociological Methods \& Research, 21(2), 230-258. https://doi.org/10.1177/0049124192021002005

Caniëls, M. C., Chiocchio, F., \& van Loon, N. P. (2019). Collaboration in project teams: The role of mastery and performance climates. International Journal of Project Management, 37(1), 1-13. https://doi.org/10.1016/j.ijproman.2018.09.006

Cao, D., Li, H., Wang, G., \& Zhang, W. (2016). Linking the motivations and practices of design organizations to implement building information modeling in construction projects: Empirical study in China. Journal of Management in Engineering, 32(6), 04016013.

https://doi.org/10.1061/(ASCE)ME.1943-5479.0000453

Chan, A. P. C., Ma, X., Yi, W., Zhou, X., \& Xiong, F. (2018). Critical review of studies on building information modeling (BIM) in project management. Frontiers of Engineering Management, 5(3), 394-406. https://doi.org/10.15302/J-FEM-2018203

Cheng, J. C., Lu, Q., \& Deng, Y. (2016). Analytical review and evaluation of civil information modeling. Automation in Construction, 67, 31-47. https://doi.org/10.1016/j.autcon.2016.02.006

Closs, D. J., Jacobs, M. A., Swink, M., \& Webb, G. S. (2008). Toward a theory of competencies for the management of product complexity: six case studies. Journal of Operations Management, 26(5), 590-610. https://doi.org/10.1016/j.jom.2007.10.003

Coda, R., da Silva, D., \& Custodio, I. (2015). Multidimensional configurations of the organizational climate construct. The International Journal of Human Resource Management, 26(14), 1827-1847. https://doi.org/10.1080/09585192.2014.962561 
Colley, S. K., \& Neal, A. (2012). Automated text analysis to examine qualitative differences in safety schema among upper managers, supervisors and workers. Safety Science, 50(9), 1775-1785. https://doi.org/10.1016/j.ssci.2012.04.006

Crane, T. G., Felder, J. P., Thompson, P. J., Thompson, M. G., \& Sanders, S. R. (1999). Partnering measures. Journal of Management in Engineering, 15(2), 37-42. https://doi.org/10.1061/ (ASCE)0742-597X(1999)15:2(37)

Crawshaw, J. R., \& Game, A. (2015). The role of line managers in employee career management: An attachment theory perspective. The International Journal of Human Resource Management, 26(9), 1182-1203.

https://doi.org/10.1080/09585192.2014.934886

Dabke, S., Salem, O., Genaidy, A., \& Daraiseh, N. (2008). Job satisfaction of women in construction trades. Journal of Construction Engineering and Management, 134(3), 205-216. https://doi.org/10.1061/(ASCE)0733-9364(2008)134:3(205)

Dahl, Ø., \& Olsen, E. (2013). Safety compliance on offshore platforms: A multi-sample survey on the role of perceived leadership involvement and work climate. Safety Science, 54, 17-26. https://doi.org/10.1016/j.ssci.2012.11.003

Davidson, J., Fowler, J., Pantazis, C., Sannino, M., Walker, J., Sheikhkhoshkar, M., \& Rahimian, F. P. (2020). Integration of VR with BIM to facilitate real-time creation of bill of quantities during the design phase: A proof of concept study. Frontiers of Engineering Management, 7, 396-403.

https://doi.org/10.1007/s42524-019-0039-y

Davies, R., \& Harty, C. (2013). Implementing 'Site BIM': A case study of ICT innovation on a large hospital project. Automation in Construction, 30, 15-24.

https://doi.org/10.1016/j.autcon.2012.11.024

Davies, K., McMeel, D. J., \& Wilkinson, S. (2017). Making friends with Frankenstein: hybrid practice in BIM. Engineering, Construction and Architectural Management, 24(1), 78-93.

https://doi.org/10.1108/ECAM-04-2015-0061

De Beuckelaer, A., Lievens, F., \& Swinnen, G. (2007). Measurement equivalence in the conduct of a global organizational survey across countries in six cultural regions. Journal of Occupational and Organizational Psychology, 80(4), 575-600. https://doi.org/10.1348/096317907X173421

Den Hartog, D. N., Boon, C., Verburg, R. M., \& Croon, M. A. (2013). HRM, communication, satisfaction, and perceived performance: A cross-level test. Journal of Management, 39(6), 1637-1665. https://doi.org/10.1177/0149206312440118

Denison, D. R. (1996). What is the difference between organizational culture and organizational climate? A native's point of view on a decade of paradigm wars. The Academy of Management Review, 21(3), 619-654.

https://doi.org/10.5465/amr.1996.9702100310

Ding, Z., Zuo, J., Wu, J., \& Wang, J. (2015). Key factors for the BIM adoption by architects: A China study. Engineering, Construction and Architectural Management, 22(6), 732-748. https://doi.org/10.1108/ECAM-04-2015-0053

Downey, H. K., Don, H., \& Slocum Jr, J. W. (1975). Congruence between individual needs, organizational climate, job satisfaction and performance. Academy of Management Journal, 18(1), 149-155. https://doi.org/10.2307/255634

Durcikova, A., Fadel, K. J., Butler, B. S., \& Galletta, D. F. (2011). Research note - knowledge exploration and exploitation: the impacts of psychological climate and knowledge management system access. Information Systems Research, 22(4), 855-866. https://doi.org/10.1287/isre.1100.0286

Eriksson, P. E. (2008). Procurement effects on coopetition in client-contractor relationships. Journal of Construction Engi- neering and Management, 134(2), 103-111.

https://doi.org/10.1061/(ASCE)0733-9364(2008)134:2(103)

Fairhurst, G. T., Green, S., \& Courtright, J. (1995). Inertial forces and the implementation of a socio-technical systems approach: A communication study. Organization Science, 6(2), 168-185. https://doi.org/10.1287/orsc.6.2.168

Fan, S., \& Shen, Q. (2011). The effect of using group decision support systems in value management studies: An experimental study in Hong Kong. International Journal of Project Management, 29(1), 13-25.

https://doi.org/10.1016/j.ijproman.2010.01.008

Farghaly, K., Abanda, F. H., Vidalakis, C., \& Wood, G. (2018). Taxonomy for BIM and asset management semantic interoperability. Journal of Management in Engineering, 34(4), 04018012 . https://doi.org/10.1061/(ASCE)ME.1943-5479.0000610

Farshchian, M. M., Heravi, G., \& AbouRizk, S. (2017). Optimizing the owner's scenarios for budget allocation in a portfolio of projects using agent-based simulation. Journal of Construction Engineering and Management, 143(7), 04017022.

https://doi.org/10.1061/(ASCE)CO.1943-7862.0001315

Fee, A., Heizmann, H., \& Gray, S. J. (2017). Towards a theory of effective cross-cultural capacity development: the experiences of Australian international NGO expatriates in Vietnam. The International Journal of Human Resource Management, 28(14), 2036-2061.

https://doi.org/10.1080/09585192.2015.1093015

Ganbat, T., Chong, H.-Y., \& Liao, P.-C. (2020). Mapping BIM uses for risk mitigation in international construction projects. Advances in Civil Engineering, Article ID 5143879. https://doi.org/10.1155/2020/5143879

Garbarino, E., \& Johnson, M. S. (1999). The different roles of satisfaction, trust, and commitment in customer relationships. Journal of Marketing, 63(2), 70-87. https://doi.org/10.1177/002224299906300205

Gil, N., \& Tether, B. S. (2011). Project risk management and design flexibility: Analysing a case and conditions of complementarity. Research Policy, 40(3), 415-428. https://doi.org/10.1016/j.respol.2010.10.011

González-Romá, V., Fortes-Ferreira, L., \& Peiró, J. M. (2009). Team climate, climate strength and team performance. A longitudinal study. Journal of Occupational and Organizational Psychology, 82(3), 511-536. https://doi.org/10.1348/096317908X370025

Grabowski, M., Rizzo, C., \& Graig, T. (2016). Data challenges in dynamic, large-scale resource allocation in remote regions. Safety Science, 87, 76-86.

https://doi.org/10.1016/j.ssci.2016.03.021

Green, A. E., Dishop, C. R., \& Aarons, G. A. (2016). Organizational stress as moderator of relationship between mental health provider adaptability and organizational commitment. Psychiatric Services, 67(10), 1103-1108. https://doi.org/10.1176/appi.ps.201500191

Gu, N., \& London, K. (2010). Understanding and facilitating BIM adoption in the AEC industry. Automation in Construction, 19(8), 988-999. https://doi.org/10.1016/j.autcon.2010.09.002

Hannevik, M. B., Lone, J. A., Bjørklund, R., Bjørkli, C. A., \& Hoff, T. (2014). Organizational climate in large-scale projects in the oil and gas industry: A competing values perspective. International Journal of Project Management, 32(4), 687-697. https://doi.org/10.1016/j.ijproman.2013.08.006

Häußler, M., \& Borrmann, A. (2020). Model-based quality assurance in railway infrastructure planning. Automation in Construction, 109, 102971.

https://doi.org/10.1016/j.autcon.2019.102971 
Hemmasi, M., Downes, M., \& Varner, I. I. (2010). An empirically-derived multidimensional measure of expatriate success: reconciling the discord. The International Journal of Human Resource Management, 21(7), 982-998.

https://doi.org/10.1080/09585191003783447

Hemmelgarn, A. L., James, L. R., Ladd, R. T., \& Mitchell, T. R. (1995). Testing for cross-situational-consistency: A confirmatory factor analytic approach. Journal of Management, 21(1), 121-139. https://doi.org/10.1177/014920639502100108

Heravi, G., Kebria, M. F., \& Rostami, M. (2019). Integrating the production and the erection processes of pre-fabricated steel frames in building projects using phased lean management. Engineering, Construction and Architectural Management. https://doi.org/10.1108/ECAM-03-2019-0133

Hinkin, T. R. (1995). A review of scale development practices in the study of organizations. Journal of Management, 21(5), 967-988. https://doi.org/10.1177/014920639502100509

Holmström, J., Singh, V., \& Främling, K. (2015). BIM as infrastructure in a Finnish HVAC actor network: enabling adoption, reuse, and recombination over a building life cycle and between projects. Journal of Management in Engineering, 31(1), A4014006.

https://doi.org/10.1061/(ASCE)ME.1943-5479.0000305

Hu, L. T., \& Bentler, P. M. (1999). Cutoff criteria for fit indexes in covariance structure analysis: Conventional criteria versus new alternatives. Structural Equation Modeling, 6(1), 1-55. https://doi.org/10.1080/10705519909540118

Hu, Y., Chan, A. P. C., Le, Y., Jiang, W.-P., Xie, L.-L., \& Hon, C. H. K. (2012). Improving megasite management performance through incentives: Lessons learned from the Shanghai Expo construction. Journal of Management in Engineering, 28(3), 330-337. https://doi.org/10.1061/(ASCE)ME.1943-5479.0000102

Hu, M., Liu, Y., Sugumaran, V., Liu, B., \& Du, J. (2019). Automated structural defects diagnosis in underground transportation tunnels using semantic technologies. Automation in Construction, 107, 102929.

https://doi.org/10.1016/j.autcon.2019.102929

Hülsheger, U. R., Anderson, N., \& Salgado, J. F. (2009). Teamlevel predictors of innovation at work: a comprehensive metaanalysis spanning three decades of research. Journal of Applied Psychology, 94(5), 1128.

https://doi.org/10.1037/a0015978

Hwang, B.-G., Shan, M., \& Looi, K.-Y. (2018). Key constraints and mitigation strategies for prefabricated prefinished volumetric construction. Journal of Cleaner Production, 183, 183193. https://doi.org/10.1016/j.jclepro.2018.02.136

Ibem, E. O., \& Laryea, S. (2014). Survey of digital technologies in procurement of construction projects. Automation in Construction, 46, 11-21.

https://doi.org/10.1016/j.autcon.2014.07.003

Janz, B. D. (1999). Self-directed teams in IS: correlates for improved systems development work outcomes. Information \& Management, 35(3), 171-192.

https://doi.org/10.1016/S0378-7206(98)00088-3

Jelodar, M. B., Yiu, T. W., \& Wilkinson, S. (2016). Relationshipquality judgment model for construction project procurement: A conjoint measurement. Journal of Construction Engineering and Management, 142(7), 04016012. https://doi.org/10.1061/(ASCE)CO.1943-7862.0001104

Jin, R., Hancock, C., Tang, L., Chen, C., Wanatowski, D., \& Yang, L. (2017a). Empirical study of BIM implementation-based perceptions among Chinese practitioners. Journal of Management in Engineering, 33(5), 04017025.

https://doi.org/10.1061/(ASCE)ME.1943-5479.0000538
Jin, R., Hancock, C. M., Tang, L., \& Wanatowski, D. (2017b). BIM investment, returns, and risks in China's AEC industries. Journal of Construction Engineering and Management, 143(12), 04017089.

https://doi.org/10.1061/(ASCE)CO.1943-7862.0001408

Jin, R., Yang, T., Piroozfar, P., Kang, B. G., Wanatowski, D., Hancock, C. M., \& Tang, L. (2018). Project-based pedagogy in interdisciplinary building design adopting BIM. Engineering, Construction and Architectural Management, 25(10), 13761397. https://doi.org/10.1108/ECAM-07-2017-0119

Jin, R., Zou, Y., Gidado, K., Ashton, P., \& Painting, N. (2019). Scientometric analysis of BIM-based research in construction engineering and management. Engineering, Construction and Architectural Management, 26(8), 1750-1776. https://doi.org/10.1108/ECAM-08-2018-0350

Jones, A. P., James, L. R., Bruni, J. R., Hornick, C. W., \& Sells, S. B. (1979). Psychological climate: Dimensions and relationships of individual and aggregated work environment perceptions. Organizational Behavior and Human Performance, 23(2), 201-250. https://doi.org/10.1016/0030-5073(79)90056-4

Joyce, W. F., \& Slocum Jr., J. W. (1984). Collective climate: Agreement as a basis for defining aggregate climates in organizations. Academy of Management Journal, 27(4), 721-742. https://doi.org/10.2307/255875

Kaewpan, W., Peltzer, K., Kalampakorn, S., \& Moolsart, S. (2017). Professional quality of life among postretired academic university employees in Thailand. Social Behavior and Personality: An International Journal, 45(4), 669-676.

https://doi.org/10.2224/sbp.5913

Kaya, N., Koc, E., \& Topcu, D. (2010). An exploratory analysis of the influence of human resource management activities and organizational climate on job satisfaction in Turkish banks. The International Journal of Human Resource Management, 21(11), 2031-2051.

https://doi.org/10.1080/09585192.2010.505104

Khan, M. A., \& Ahmad, N. S. A. (2011). Modeling link between internal service quality in human resources management and employees retention: A case of Pakistani privatized and public sector banks. African Journal of Business Management, 5(3), 949-959.

Kim, S., Chin, S., Han, J., \& Choi, C.-H. (2017). Measurement of construction BIM value based on a case study of a largescale building project. Journal of Management in Engineering, 33(6), 05017005.

https://doi.org/10.1061/(ASCE)ME.1943-5479.0000551

Kivimaki, M., \& Elovainio, M. (1999). A short version of the Team Climate Inventory: Development and psychometric properties. Journal of Occupational and Organizational Psychology, 72(2), 241-246. https://doi.org/10.1348/096317999166644

Kivimäki, M., Kuk, G., Elovainio, M., Thomson, L., Kalliomäki-Levanto, T., \& Heikkilä, A. (1997). The Team Climate Inventory (TCI) - four or five factors? Testing the structure of TCI in samples of low and high complexity jobs. Journal of Occupational and Organizational Psychology, 70(4), 375-389. https://doi.org/10.1111/j.2044-8325.1997.tb00655.x

Klein, R. (2007). Customization and real time information access in integrated eBusiness supply chain relationships. Journal of Operations Management, 25(6), 1366-1381. https://doi.org/10.1016/j.jom.2007.03.001

Koys, D. J., \& DeCotiis, T. A. (1991). Inductive measures of psychological climate. Human Relations, 44(3), 265-285. https://doi.org/10.1177/001872679104400304

Kuenzi, M., \& Schminke, M. (2009). Assembling fragments into a lens: A review, critique, and proposed research agenda for the 
organizational work climate literature. Journal of Management, 35(3), 634-717. https://doi.org/10.1177/0149206308330559

Kwon, B., Farndale, E., \& Park, J. G. (2016). Employee voice and work engagement: Macro, meso, and micro-level drivers of convergence? Human Resource Management Review, 26(4), 327-337. https://doi.org/10.1016/j.hrmr.2016.04.005

Lee, C.-Y., Chong, H.-Y., Li, Q., \& Wang, X. (2020). Joint contract - function effects on BIM-enabled EPC project performance. Journal of Construction Engineering and Management, 146(3), 04020008

https://doi.org/10.1061/(ASCE)CO.1943-7862.0001766

Lee, J.-C., \& Chen, C.-Y. (2019). Exploring the determinants of software process improvement success: A dynamic capability view. Information Development, 35(1), 6-20.

https://doi.org/10.1177/0266666917724194

Li, A., \& Cropanzano, R. (2009). Fairness at the group level: Justice climate and intraunit justice climate. Journal of Management, 35(3), 564-599. https://doi.org/10.1177/0149206308330557

Li, A., Cropanzano, R., \& Bagger, J. (2013a). Justice climate and peer justice climate. Small Group Research, 44(5), 563-592. https://doi.org/10.1177/1046496413498119

Li, T. H. Y., Ng, S. T., \& Skitmore, M. (2013b). Evaluating stakeholder satisfaction during public participation in major infrastructure and construction projects: A fuzzy approach. Automation in Construction, 29, 123-135.

https://doi.org/10.1016/j.autcon.2012.09.007

Lievens, F., Chasteen, C. S., Day, E. A., \& Christiansen, N. D. (2006). Large-scale investigation of the role of trait activation theory for understanding assessment center convergent and discriminant validity. Journal of Applied Psychology, 91(2), 247-258. https://doi.org/10.1037/0021-9010.91.2.247

Lim, D. H., \& Morris, M. L. (2006). Influence of trainee characteristics, instructional satisfaction, and organizational climate on perceived learning and training transfer. Human Resource Development Quarterly, 17(1), 85-115.

https://doi.org/10.1002/hrdq.1162

Ling, F. Y. Y., \& Loo, C. M. C. (2015). Characteristics of jobs and jobholders that affect job satisfaction and work performance of project managers. Journal of Management in Engineering, 31(3), 04014039.

https://doi.org/10.1061/(ASCE)ME.1943-5479.0000247

Liu, A. M., \& Chan, I. Y. (2017). Understanding the interplay of organizational climate and leadership in construction innovation. Journal of Management in Engineering, 33(5), 04017021. https://doi.org/10.1061/(ASCE)ME.1943-5479.0000521

Liu, Y., Van Nederveen, S., \& Hertogh, M. (2017). Understanding effects of BIM on collaborative design and construction: An empirical study in China. International Journal of Project Management, 35(4), 686-698.

https://doi.org/10.1016/j.ijproman.2016.06.007

Liu, N., Ruan, L., Jin, R., Chen, Y., Deng, X., \& Yang, T. (2019). Investigation of individual perceptions towards BIM implementation-a Chongqing case study. Engineering, Construction and Architectural Management, 26(7), 1455-1475.

https://doi.org/10.1108/ECAM-08-2018-0342

Llopis, O., \& Foss, N. J. (2016). Understanding the climate knowledge sharing relation: The moderating roles of intrinsic motivation and job autonomy. European Management Journal, 34(2), 135-144. https://doi.org/10.1016/j.emj.2015.11.009

Lu, C., Liu, J., Liu, Y., \& Liu, Y. (2019). Intelligent construction technology of railway engineering in China. Frontiers of Engineering Management, 6(4), 503-516.

https://doi.org/10.1007/s42524-019-0073-9
MacKenzie, S. B., Podsakoff, P. M., \& Podsakoff, N. P. (2011). Construct measurement and validation procedures in MIS and behavioral research: Integrating new and existing techniques. MIS Quarterly, 35(2), 293-334.

https://doi.org/10.2307/23044045

Mahalingam, A., Yadav, A. K., \& Varaprasad, J. (2015). Investigating the role of lean practices in enabling BIM adoption: Evidence from two Indian cases. Journal of Construction Engineering and Management, 141(7), 05015006. https://doi.org/10.1061/(ASCE)CO.1943-7862.0000982

Malik, S. D., \& Wilson, D. O. (1995). Factors influencing engineers' perceptions of organizational support for innovation. Journal of Engineering and Technology Management, 12(3), 201-218. https://doi.org/10.1016/0923-4748(95)00010-5

March, J. G. (1991). Exploration and exploitation in organizational learning. Organization Science, 2(1), 71-87. https://doi.org/10.1287/orsc.2.1.71

Matthews, J., Love, P. E. D., Heinemann, S., Chandler, R., Rumsey, C., \& Olatunj, O. (2015). Real time progress management: Re-engineering processes for cloud-based BIM in construction. Automation in Construction, 58, 38-47. https://doi.org/10.1016/j.autcon.2015.07.004

Mehrbod, S., Staub-French, S., Mahyar, N., \& Tory, M. (2019). Characterizing interactions with BIM tools and artifacts in building design coordination meetings. Automation in Construction, 98, 195-213.

https://doi.org/10.1016/j.autcon.2018.10.025

Melville, N., Kraemer, K., \& Gurbaxani, V. (2004). Information technology and organizational performance: An integrative model of IT business value. MIS Quarterly, 28(2), 283-322. https://doi.org/10.2307/25148636

Methot, J. R., Rosado-Solomon, E. H., \& Allen, D. G. (2018). The network architecture of human captial: A relational identity perspective. Academy of Management Review, 43(4), 723-748. https://doi.org/10.5465/amr.2016.0338

Mohamed, S. (2002). Safety climate in construction site environments. Journal of Construction Engineering and Management, 128(5), 375-384.

https://doi.org/10.1061/(ASCE)0733-9364(2002)128:5(375)

Mosher, G. A., Keren, N., Freeman, S. A., \& Hurburgh, C. (2012). Management of safety and quality and the relationship with employee decisions in country grain elevators. Journal of Agricultural Safety and Health, 18(3), 195-215.

https://doi.org/10.13031/2013.41957

Neely, A., Ng, I. C., Roy, R., Hong, P., Yang, M. G. M., \& Dobrzykowski, D. D. (2014). Strategic customer service orientation, lean manufacturing practices and performance outcomes. Journal of Service Management, 25(5), 699-723. https://doi.org/10.1108/JOSM-12-2013-0355

Olanipekun, A. O., Xia, B., Hon, C., \& Darko, A. (2018). Effect of motivation and owner commitment on the delivery performance of green building projects. Journal of Management in Engineering, 34(1), 04017039.

https://doi.org/10.1061/(ASCE)ME.1943-5479.0000559

Olawumi, T. O., \& Chan, D. W. M. (2018). Building information modelling and project information management framework for construction projects. Journal of Civil Engineering and Management, 25(1), 53-75.

https://doi.org/10.3846/jcem.2019.7841

Papadonikolaki, E. (2018). Loosely coupled systems of innovation: Aligning BIM adoption with implementation in Dutch construction. Journal of Management in Engineering, 34(6), 05018009 .

https://doi.org/10.1061/(ASCE)ME.1943-5479.0000644 
Parasuraman, S., Greenhaus, J. H., \& Granrose, C. S. (1992). Role stressors, social support, and well-being among two-career couples. Journal of Organizational Behavior, 13(4), 339-356. https://doi.org/10.1002/job.4030130403

Park, J.-H., Suh, H.-J., \& Yang, H.-D. (2007). Perceived absorptive capacity of individual users in performance of Enterprise Resource Planning (ERP) usage: The case for Korean firms. Information \& Management, 44(3), 300-312. https://doi.org/10.1016/j.im.2007.02.001

Park, H. S., Baker, C., \& Lee, D. W. (2008). Need for cognition, task complexity, and job satisfaction. Journal of Management in Engineering, 24(2), 111-117. https://doi.org/10.1061/(ASCE)0742-597X(2008)24:2(111)

Parker, C. P., Dipboye, R. L., \& Jackson, S. L. (1995). Perceptions of organizational politics: An investigation of antecedents and consequences. Journal of Management, 21(5), 891-912. https://doi.org/10.1177/014920639502100505

Pasmore, W. A., \& Khalsa, G. S. (1993). The contributions of Eric Trist to the social engagement of social science. Academy of Management Review, 18(3), 546-569.

https://doi.org/10.5465/amr.1993.9309035150

Patterson, M. G., West, M. A., Shackleton, V. J., Dawson, J. F., Lawthom, R., Maitlis, S., Robinson, D. L., \& Wallace, A. M. (2005). Validating the organizational climate measure: links to managerial practices, productivity and innovation. Journal of Organizational Behavior, 26(4), 379-408.

https://doi.org/10.1002/job.312

Payne, R. L., \& Mansfield, R. (1973). Relationships of perceptions of organizational climate to organizational structure, context, and hierarchical position. Administrative Science Quarterly, 18(4), 515-526. https://doi.org/10.2307/2392203

Pearce, C. L., \& Sims Jr., H. P. (2002). Vertical versus shared leadership as predictors of the effectiveness of change management teams: An examination of aversive, directive, transactional, transformational, and empowering leader behaviors. Group Dynamics: Theory, Research, and Practice, 6(2), 172197. https://doi.org/10.1037/1089-2699.6.2.172

Poirier, E. A., Forgues, D., \& Staub-French, S. (2017). Understanding the impact of BIM on collaboration: a Canadian case study. Building Research and Information, 45(6), 681-695. https://doi.org/10.1080/09613218.2017.1324724

Quinn, R. E., \& Rohrbaugh, J. (1981). A competing values approach to organizational effectiveness. Public Productivity Review, 5(2), 122-140. https://doi.org/10.2307/3380029

Quinn, R. E., \& Rohrbaugh, J. (1983). A spatial model of effectiveness criteria: Towards a competing values approach to organizational analysis. Management Science, 29(3), 363-377. https://doi.org/10.1287/mnsc.29.3.363

Rafferty, A. E., Jimmieson, N. L., \& Armenakis, A. A. (2013). Change readiness: A multilevel review. Journal of Management, 39(1), 110-135. https://doi.org/10.1177/0149206312457417

Reich, B. H., \& Benbasat, I. (1996). Measuring the linkage between business and information technology objectives. MIS Quarterly, 20(1), 55-81. https://doi.org/10.2307/249542

Remneland-Wikhamn, B., \& Wikhamn, W. (2011). Open innovation climate measure: The introduction of a validated scale. Creativity and Innovation Management, 20(4), 284-295. https://doi.org/10.1111/j.1467-8691.2011.00611.x

Ren, G., Li, H., Ding, R., Zhang, J., Boje, C., \& Zhang, W. (2019). Developing an information exchange scheme concerning value for money assessment in Public-Private Partnerships. Journal of Building Engineering, 25, 100828. https://doi.org/10.1016/j.jobe.2019.100828
Romm, N. R. (2013). Employing questionnaires in terms of a constructivist epistemological stance: reconsidering researchers' involvement in the unfolding of social life. International Journal of Qualitative Methods, 12(1), 652-669.

https://doi.org/10.1177/160940691301200136

Rosenthal, M. M., \& Holmes, E. R. (2018). The professional culture of community pharmacy and the provision of MTM services. Pharmacy, 6(2), 25.

https://doi.org/10.3390/pharmacy6020025

Sackey, E., Tuuli, M., \& Dainty, A. (2015). Sociotechnical systems approach to BIM implementation in a multidisciplinary construction context. Journal of Management in Engineering, 31(1), A4014005.

https://doi.org/10.1061/(ASCE)ME.1943-5479.0000303

Sanguinetti, P., Abdelmohsen, S., Lee, J., Lee, J., Sheward, H., \& Eastman, C. (2012). General system architecture for BIM: An integrated approach for design and analysis. Advanced Engineering Informatics, 26(2), 317-333.

https://doi.org/10.1016/j.aei.2011.12.001

Santos, R., Costa, A. A., \& Grilo, A. (2017). Bibliometric analysis and review of Building Information Modelling literature published between 2005 and 2015. Automation in Construction, 80, 118-136. https://doi.org/10.1016/j.autcon.2017.03.005

Saunders, L. (1999). A brief history of educational 'value added': how did we get to where we are? School Effectiveness and School Improvement, 10(2), 233-256.

https://doi.org/10.1076/sesi.10.2.233.3507

Schulte, M., Ostroff, C., Shmulyian, S., \& Kinicki, A. (2009). Organizational climate configurations: Relationships to collective attitudes, customer satisfaction, and financial performance. Journal of Applied Psychology, 94(3), 618-634. https://doi.org/10.1037/a0014365

Selçuk Çıdık, M., Boyd, D., \& Thurairajah, N. (2017). Innovative capability of building information modeling in construction design. Journal of Construction Engineering and Management, 143(8), 04017047.

https://doi.org/10.1061/(ASCE)CO.1943-7862.0001337

Serrador, P., \& Turner, R. (2015). The relationship between project success and project efficiency. Project Management Journal, 46(1), 30-39. https://doi.org/10.1002/pmj.21468

Shen, L., Wu, Y., \& Zhang, X. (2011). Key assessment indicators for the sustainability of infrastructure projects. Journal of Construction Engineering and Management, 137(6), 441-451. https://doi.org/10.1061/(ASCE)CO.1943-7862.0000315

Shen, Y., Tuuli, M. M., Xia, B., Koh, T. Y., \& Rowlinson, S. (2015). Toward a model for forming psychological safety climate in construction project management. International Journal of Project Management, 33(1), 223-235.

https://doi.org/10.1016/j.ijproman.2014.04.009

Sinha, S. K., \& McKim, R. A. (2000). Artificial neural network for measuring organizational effectiveness. Journal of Computing in Civil Engineering, 14(1), 9-14. https://doi.org/10.1061/(ASCE)0887-3801(2000)14:1(9)

Solla, M., Ismail, L. H., Shaarani, A. s. M., \& Milad, A. (2019). Measuring the feasibility of using of BIM application to facilitate GBI assessment process. Journal of Building Engineering, 25, 100821. https://doi.org/10.1016/j.jobe.2019.100821

Song, J., Migliaccio, G. C., Wang, G., \& Lu, H. (2017). Exploring the influence of system quality, information quality, and external service on BIM user satisfaction. Journal of Management in Engineering, 33(6), 04017036. https://doi.org/10.1061/(ASCE)ME.1943-5479.0000549 
Stewart, R. A., \& Mohamed, S. (2003). Evaluating the value IT adds to the process of project information management in construction. Automation in Construction, 12(4), 407-417. https://doi.org/10.1016/S0926-5805(03)00006-2

Sun, Y., \& Jeyaraj, A. (2013). Information technology adoption and continuance: A longitudinal study of individuals' behavioral intentions. Information \& Management, 50(7), 457-465. https://doi.org/10.1016/j.im.2013.07.005

Sung, S. Y., Choi, J. N., \& Kang, S. C. (2017). Incentive pay and firm performance: Moderating roles of procedural justice climate and environmental turbulence. Human Resource Management, 56(2), 287-305. https://doi.org/10.1002/hrm.21765

Swuste, P., van Gulijk, C., Groeneweg, J., Zwaard, W., Lemkowitz, S., \& Guldenmund, F. (2020). From clapham junction to macondo, deepwater horizon: Risk and safety management in high-tech-high-hazard sectors: A review of English and Dutch literature: 1988-2010. Safety Science, 121, 249-282. https://doi.org/10.1016/j.ssci.2019.08.031

Tabassi, A. A., Ramli, M., \& Bakar, A. H. A. (2012). Effects of training and motivation practices on teamwork improvement and task efficiency: The case of construction firms. International Journal of Project Management, 30(2), 213-224. https://doi.org/10.1016/j.ijproman.2011.05.009

Tinsley, H. E. A., \& Tinsley, D. J. (1987). Uses of factor analysis in counseling psychology research. Journal of Counseling Psychology, 34(4), 414-424. https://doi.org/10.1037/0022-0167.34.4.414

Uhrin, Á., Bruque-Cámara, S., \& Moyano-Fuentes, J. (2017). Lean production, workforce development and operational performance. Management Decision, 55(1), 103-118. https://doi.org/10.1108/MD-05-2016-0281

Van De Voorde, K., Van Veldhoven, M., \& Paauwe, J. (2010). Time precedence in the relationship between organizational climate and organizational performance: A cross-lagged study at the business unit level. The International Journal of Human Resource Management, 21(10), 1712-1732.

https://doi.org/10.1080/09585192.2010.500491

Van Vianen, A. E., \& Kmieciak, Y. M. (1998). The match between recruiters' perceptions of organizational climate and personality of the ideal applicant for a management position. International Journal of Selection and Assessment, 6(3), 153-163. https://doi.org/10.1111/1468-2389.00086

Van Vianen, A. E., Rosenauer, D., Homan, A. C., Horstmeier, C. A., \& Voelpel, S. C. (2018). Career mentoring in context: A multilevel study on differentiated career mentoring and career mentoring climate. Human Resource Management, 57(2), 583-599. https://doi.org/10.1002/hrm.21879

Wang, X., Love, P. E. D., Kim, M. J., Park, C.-S., Sing, C.-P., \& Hou, L. (2013). A conceptual framework for integrating building information modeling with augmented reality. $A u$ tomation in Construction, 34, 37-44.

https://doi.org/10.1016/j.autcon.2012.10.012

Wang, X., Truijens, M., Hou, L., Wang, Y., \& Zhou, Y. (2014). Integrating Augmented Reality with Building Information Modeling: Onsite construction process controlling for liquefied natural gas industry. Automation in Construction, 40, 96-105. https://doi.org/10.1016/j.autcon.2013.12.003

West, M. A., Smith, H., Feng, W. L., \& Lawthom, R. (1998). Research excellence and departmental climate in British universities. Journal of Occupational and Organizational Psychology, 71(3), 261-281.

https://doi.org/10.1111/j.2044-8325.1998.tb00676.x

Winby, S., \& Mohrman, S. A. (2018). Digital sociotechnical system design. The Journal of Applied Behavioral Science, 54(4), 399-423. https://doi.org/10.1177/0021886318781581
Wisse, B., Rus, D., Keller, A. C., \& Sleebos, E. (2019). "Fear of losing power corrupts those who wield it": the combined effects of leader fear of losing power and competitive climate on leader self-serving behavior. European Journal of Work and Organizational Psychology, 28(6), 742-755. https://doi.org/10.1080/1359432X.2019.1635584

Won, J., \& Lee, G. (2016). How to tell if a BIM project is successful: A goal-driven approach. Automation in Construction, 69, 34-43. https://doi.org/10.1016/j.autcon.2016.05.022

Wong, J. K. W., \& Zhou, J. (2015). Enhancing environmental sustainability over building life cycles through green BIM: A review. Automation in Construction, 57, 156-165. https://doi.org/10.1016/j.autcon.2015.06.003

Wu, W., \& Issa, R. R. A. (2015). BIM execution planning in green building projects: LEED as a use case. Journal of Management in Engineering, 31(1), A4014007.

https://doi.org/10.1061/(ASCE)ME.1943-5479.0000314

Wu, W., Mayo, G., McCuen, T. L., Issa, R. R. A., \& Smith, D. K. (2018). Building information modeling body of knowledge. I: Background, framework, and initial development. Journal of Construction Engineering and Management, 144(8), 04018065. https://doi.org/10.1061/(ASCE)CO.1943-7862.0001518

Xu, J., Jin, R., Piroozfar, P., Wang, Y., Kang, B.-G., Ma, L., Wanatoskim D., \& Yang, T. (2018). Constructing a BIM climate-based framework: regional case study in China. Journal of Construction Engineering and Management, 144(11), 04018105 .

https://doi.org/10.1061/(ASCE)CO.1943-7862.0001568

Yamasaki, K., \& Nishida, N. (2009). The relationship between three types of aggression and peer relations in elementary school children. International Journal of Psychology, 44(3), 179-186. https://doi.org/10.1080/00207590701656770

Yang, J., Shen, G. Q., Drew, D. S., \& Ho, M. (2010). Critical success factors for stakeholder management: Construction practitioners' perspectives. Journal of Construction Engineering and Management, 136(7), 778-786.

https://doi.org/10.1061/(ASCE)CO.1943-7862.0000180

Yin, X., Liu, H., Chen, Y., \& Al-Hussein, M. (2019). Building information modelling for off-site construction: Review and future directions. Automation in Construction, 101, 72-91. https://doi.org/10.1016/j.autcon.2019.01.010

Yuan, J., Xu, W., Xia, B., \& Skibniewski, M. J. (2018). Exploring key indicators of residual value risks in China's public-private partnership projects. Journal of Management in Engineering, 34(1), 04017046. https://doi.org/10.1061/(ASCE)ME.1943-5479.0000561

Zhang, S., Pan, F., Wang, C., Sun, Y., \& Wang, H. (2017). BIMBased collaboration platform for the management of EPC projects in hydropower engineering. Journal of Construction Engineering and Management, 143(12), 04017087. https://doi.org/10.1061/(ASCE)CO.1943-7862.0001403

Zheng, L., Lu, W., Chen, K., Chau, K. W., \& Niu, Y. (2017). Benefit sharing for BIM implementation: Tackling the moral hazard dilemma in inter-firm cooperation. International Journal of Project Management, 35(3), 393-405. https://doi.org/10.1016/j.ijproman.2017.01.006

Zheng, X., Lu, Y., Li, Y., Le, Y., \& Xiao, J. (2019). Quantifying and visualizing value exchanges in building information modeling (BIM) projects. Automation in Construction, 99, 91-108. https://doi.org/10.1016/j.autcon.2018.12.001 